Original paper

\title{
Magnetic fabric and emplacement of dykes of lamprophyres and related rocks of the Central Bohemian Dyke Swarm (Central European Variscides)
}

\author{
František HROUDA ${ }^{1,2 *}$, Kryštof VERNER ${ }^{1,3}$, Šárka KUBÍNOVÁ ${ }^{1}$, David BURIÁNEK ${ }^{4}$, Shah Wali \\ FARYAD ${ }^{1}$, Marta CHLUPÁČOVÁ ${ }^{5}$, František V. HOLUB ${ }^{1 \dagger}$ \\ ${ }^{1}$ Institute of Petrology and Structural Geology, Charles University, Albertov 6, 12843 Prague 2; hrouda@agico.cz \\ ${ }^{2}$ Agico Inc., Ječná 29a, 62100 Brno, Czech Republic \\ ${ }^{3}$ Czech Geological Survey, Klárov 3, 11821 Prague 1, Czech Republic \\ ${ }^{4}$ Czech Geological Survey, Leitnerova 22, 62100 Brno, Czech Republic \\ ${ }^{5}$ Boháčova 866/4, 14900 Prague 4, Czech Republic \\ * Corresponding author \\ ${ }^{+}$Deceased
}

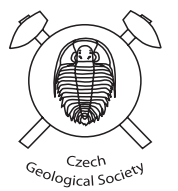

Numerous dykes of lamprophyres and various types of granitoid, syenitoid, dioritoid, and gabbroid porphyries of Variscan age crop out in the area of the Central Bohemian Plutonic Complex and adjacent high- to low-grade metamorphic units of the Moldanubian Zone and Teplá-Barrandian Unit. Magnetic fabric in fourteen dykes of lamprophyres and related rocks was investigated. Mostly, the magnetic foliation is roughly parallel to the dyke plane and the magnetic lineation is horizontal with the relics of originally steep fabrics. This type of magnetic fabric originated through magma flow in which the larger surfaces of the magnetic minerals were oriented parallel to the dyke plane and their longer dimensions were parallel to the magma flow. In two localities, the so-called inverse fabrics were found in which the maximum and minimum susceptibility directions were swapped.

The dykes of lamprophyres and related rocks were emplaced into already juxtaposed and cooled Teplá-Barrandian Zone, Central Bohemian Plutonic Complex and western Moldanubian Zone not later than 339 Ma. Parallel orientation of dykes giving a steep intrusive contacts mainly in $\mathrm{W}(\mathrm{NW})-\mathrm{E}(\mathrm{SE})$ trend was caused by the regional stress field of $\sim \mathrm{WNW}-\mathrm{ESE}$ convergence (arc-parallel stretching) during the Variscan Orogeny.

Keywords: anisotropy of magnetic susceptibility (AMS), dyke-swarm, emplacement, Bohemian Massif, Variscides

Received: 12 July, 2016; accepted: 2 January, 2017; handling editor: V. Rapprich

The online version of this article (doi: 10.3190/jgeosci.222) contains supplementary electronic material.

\section{Introduction}

Magma ascent and emplacement in dykes is one of important mechanisms of the mass transport within the Earth's crust and the upper mantle. Structural aspects of this mass transfer can be advantageously studied using the anisotropy of magnetic susceptibility (AMS), which is a rapid and efficient geophysical (petrophysical) method for investigation of the preferred orientation of magnetic minerals (magnetic fabric) in rocks (for more details see Tarling and Hrouda 1993). This method is very sensitive and extremely fast (an order of magnitude faster than the classical methods of structural analysis). In addition, there are extensive data-bases of the AMS data in various volcanic bodies and dykes (for summary see CañónTapia 2004; Raposo 2011) and their deformed equivalents (e.g., Henry 1977; Hrouda and Prrichystal 1995).

In dykes, the most common magnetic fabric type is characterized by the magnetic foliation approximately parallel to the dyke plane and the magnetic lineation, also parallel to the dyke plane, can be vertical, horizontal, or even oblique according to the magma flow in a dyke (e.g. Knight and Walker 1988; Rochette et al. 1991; Ernst and Baragar 1992; Raposo 2011). This fabric type was called normal by Rochette et al. (1991) or Type I by Raposo and Ernesto (1995) (see Fig. 1). During magma flow, the larger surfaces of magnetic minerals align approximately parallel to the dyke, while the longer dimensions orient parallel to the magma flow direction. The second and much less frequent type is characterized by the approximately perpendicular orientation of magnetic foliation to the dyke plane and magnetic lineation parallel to the dyke (intermediate fabric of Rochette et al. 1991, Type II fabric of Raposo and Ernesto 1995; Fig. 1). This orientation may originate through a compaction of a static magma column along the dyke and the magnetic minerals reorient with their larger surfaces perpendicular to the flow direction (Park et al. 1988; Bates and Mushayandebvu 1995; Raposo and Ernesto 1995). The third, scarce type is characterized by the magnetic foliation and magnetic lineation perpendicu- 


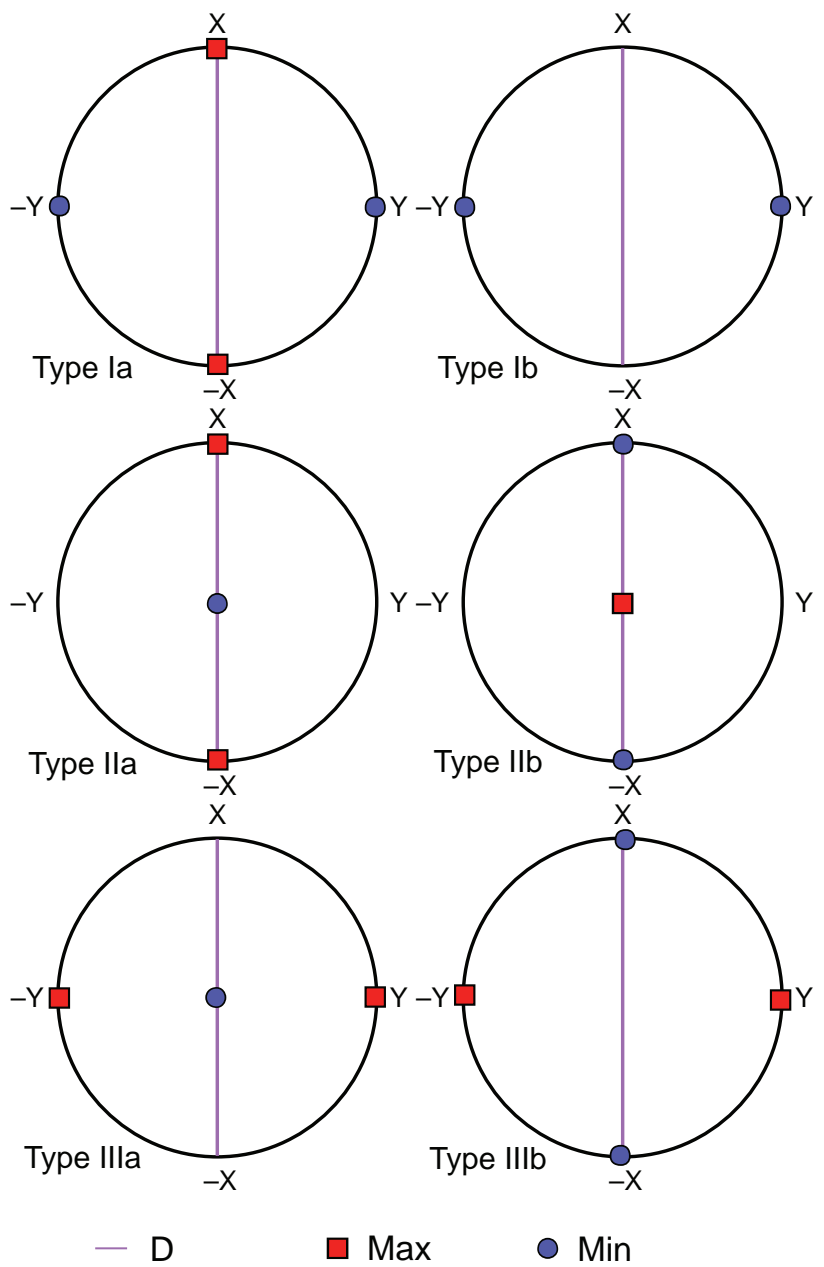

Fig. 1 Schematic sketch of variable types of magnetic fabrics in dykes. Dyke plane is denoted by vertical great circle in grey. Equal-area projection on lower hemisphere. Adapted from Raposo and Ernesto (1995).

lar to the dyke. This type was termed reverse by Rochette et al. (1991) or inverse by Raposo (2011) or Type III by Raposo and Ernesto (1995) (Fig. 1). This magnetic fabric is attributed to secondary processes such as hydrothermal alteration (Rochette et al. 1991) or to single domain effect if very small magnetic grains carry the AMS (Stephenson et al. 1986). There is also a fourth type showing almost random orientations of magnetic foliations and lineations, which may result from very complex flow patterns or from severe post-magmatic changes of magnetic minerals (Hrouda 1985; Raposo 2011).

The relationship between magnetic fabric and dyke orientation described in preceding paragraph was revealed through investigation of crustally derived intermediate to mafic dykes. Much less information is available about magnetic fabric in mafic and ultramafic ultrapotassic dykes (e.g. Holub et al. 2012; Machek et al. 2014) generated from the mantle (e.g. Edgar and Mitchell 1997; Guo et al. 2006; Chalapathi Rao and Srivastava 2012; Gupta 2015).

The (ultra-) potassic dykes are abundant late members of the Central Bohemian Dyke Swarm spatially associ- ated to the Variscan Central Bohemian Plutonic Complex (CBPC) but also cut the adjacent parts of the upper-crustal Teplá-Barrandian Unit and mid- to lower crustal western Moldanubian Zone (Fig. 2). The Central Bohemian Dyke Swarm has an asymmetric area of extent, elongated predominantly in the NNE-SSW direction along the border between western Moldanubian and Teplá-Barrandian zones. The individual dykes are approximately perpendicular to the asymmetric Central Bohemian Dyke Swarm and are mostly perpendicular to the regional fabrics in host units. The studied dykes penetrate the older medium- and high-K calc-alkaline granitoid rocks of the CBPC dated at 354.1 +3.5 Ma (Janoušek et al. 2004) and 346.4 $\pm 1.1 \mathrm{Ma}$ (Janoušek et al. 2010), respectively. Concurrently they must be older than the emplacement of the Tábor Pluton (dated at 336.9 $\pm 0.6 \mathrm{Ma}$; Janoušek et al. 2013). This means that despite the extensive area of occurrence and compositional variations these dykes show only a limited variation in age ( 346 to 337 Ma; Holub 1997; Holub et al. 1997a).

In this paper we discuss the petrology and AMS of the dykes of calc-alkaline and potassic lamprophyres and related rocks of the Central Bohemian Dyke Swarm. This study aims to analyse the magma ascent and emplacement during the dyke formation that occurred along the western border of the Moldanubian Zone at the contact with the Teplá-Barrandian Unit. This event dated the final stage of regional $\sim$ WNW-ESE convergence and crustal exhumation that occurred at around $340 \mathrm{Ma}$ (e.g. Schulmann et al. 2009).

\section{Geological setting}

\subsection{Metamorphic and magmatic units hosting the dyke swarm}

\subsubsection{Teplá-Barrandian Unit}

The Teplá-Barrandian Unit consists of low- to mediumgrade Neoproterozoic metasediments, originally forming a part of the Cadomian accretionary wedge, later intruded by Cambro-Ordovician granitoids and containing unmetamorphosed mid-Cambrian to mid-Devonian volcanosedimentary sequences (for review see Chlupáč et al. 1998; Schulmann et al. 2009; Žák et al. 2014; Hajná et al. 2017).

\subsubsection{Moldanubian Zone}

The Moldanubian Zone represents exhumed lower- to mid-crustal orogenic root that builds up the internal part of the Variscan orogenic belt in central Europe (Fig. 2). The Moldanubian Zone experienced polyphase metamorphism and complex deformational history (e.g. Franke 2006; Schulmann et al. 2009; Faryad et al. 2010; Lardeaux et al. 2014). In general, the overall structure of the orogenic root 


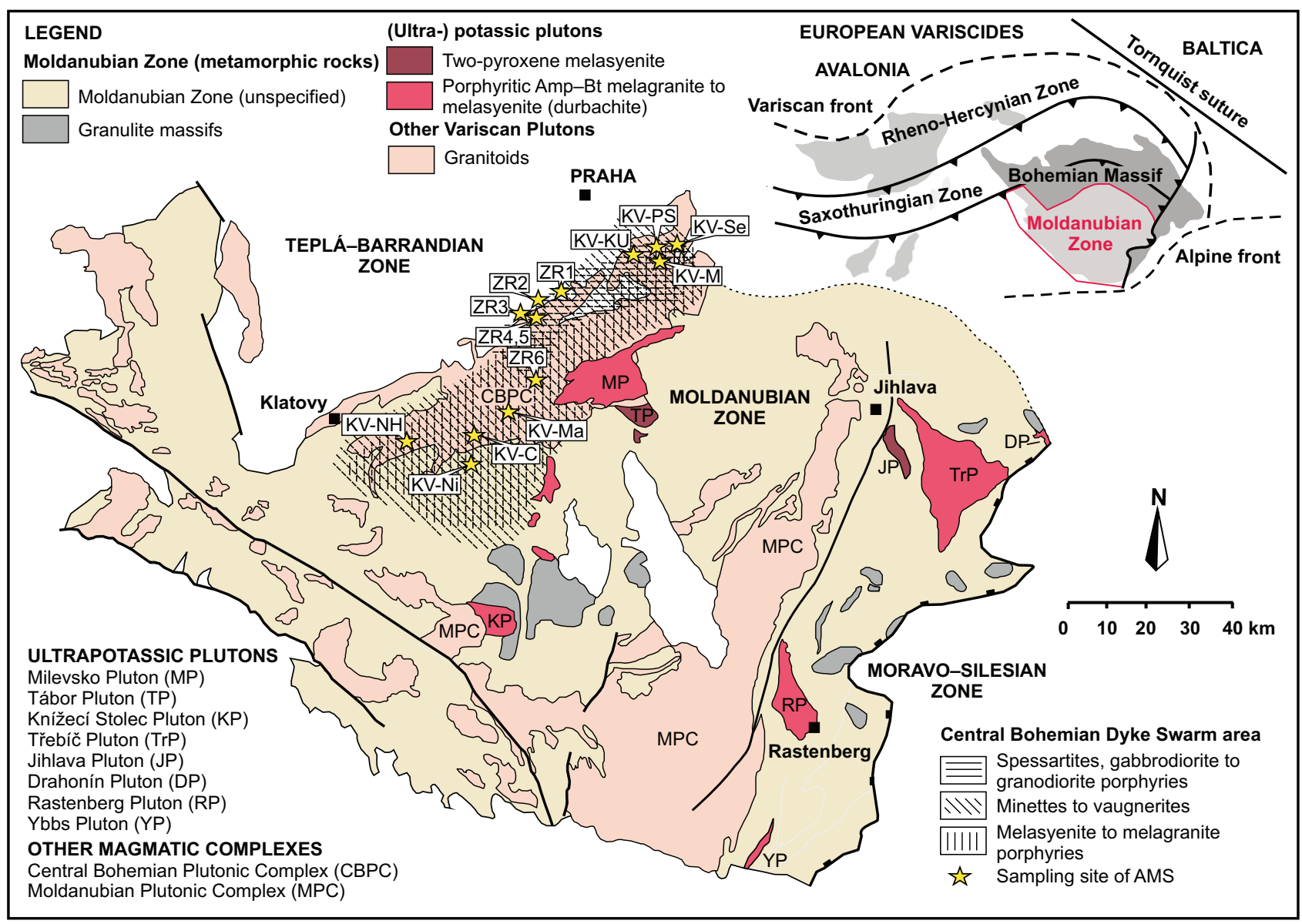

Fig. 2 Geological sketch map of the Bohemian Massif and its position in the European Variscides (inset). Geological map of the southern and central parts of the Bohemian Massif showing the extent of occurrence of the Central Bohemian Dyke Swarm (hatch pattern) and locations of the dykes investigated. Adapted from Chlupáč et al. (2002).

resulted from stacking of several lithotectonic units at $\sim 360$ to 345 Ma followed by HT/LP metamorphism, anatexis and late-Variscan wrench tectonics (for review see Schulmann et al. 2009; Žák et al. 2014). The Moldanubian Zone consists of metasedimentary sequences of Neoproterozoic to Lower Palaeozoic protolith age (Košler et al. 2014) dominated by sillimanite-biotite ( \pm cordierite) paragneisses to migmatites with variable presence of small bodies of metaquartzites, marbles, calc-silicate rocks, graphite-bearing schists and amphibolites (e.g. Urban and Synek 1995).

The Variscan geodynamic evolution in the Moldanubian Zone was characterized by 380 to 335 Ma subduction-collision tectonics and metamorphism, magmatic activity, and fast exhumation and cooling from $\sim 346$ to 335 Ma onward (e.g. Schulmann et al. 2009; Dörr and Zulauf 2010; Žák et al. 2012, 2014; Faryad et al. 2013).

\subsubsection{Central Bohemian Plutonic Complex (CBPC)}

Syn-collisional Late Devonian-Early Carboniferous ( $\sim 370$ to $340 \mathrm{Ma}$ ) crustal thickening broadly overlapped with the emplacement of medium- and high-K calc-alkaline, I-type plutons of the prevailing part of the CBPC (Holub et al. 1997a, b; Žák et al. 2011). The CBPC crops out along significant tectonic boundary between the upper-crustal Barrandian Unit (eastern Teplá-Barrandian Zone) and high-grade western part of the Moldanubian Zone (WMZ). It covers an area of about $3,000 \mathrm{~km}^{2}$ and comprises a number of various granitoid and subordinate mafic rocks that can be divided into several suites (e.g. Janoušek et al. 1995, 2000; Holub et al. 1997b; Žák et al. 2005b).

Widely distributed are mainly medium-K calc-alkaline rocks (quartz diorites to granodiorites of the Sázava Pluton) dated by conventional zircon U-Pb method to 354.1 \pm 3.5 Ma (Janoušek et al. 2004). The high-K to shoshonitic rocks (monzogabbros, quartz monzonites to granodiorites of the Blatná Composite Pluton) gave the SHRIMP U-Pb zircon age of $346.4 \pm 1.1 \mathrm{Ma}$ (Janoušek et al. 2010). The ultrapotassic rocks (melasyenites to melagranites of the durbachitic Milevsko and Tábor plutons) were dated at $343 \pm 6 \mathrm{Ma}$ by $\mathrm{Pb}-\mathrm{Pb}$ zircon evaporation (Holub et al. 1997a) and at 336.9 $\pm 0.6 \mathrm{Ma}$ by conventional U-Pb dating of zircon (Janoušek et al. 

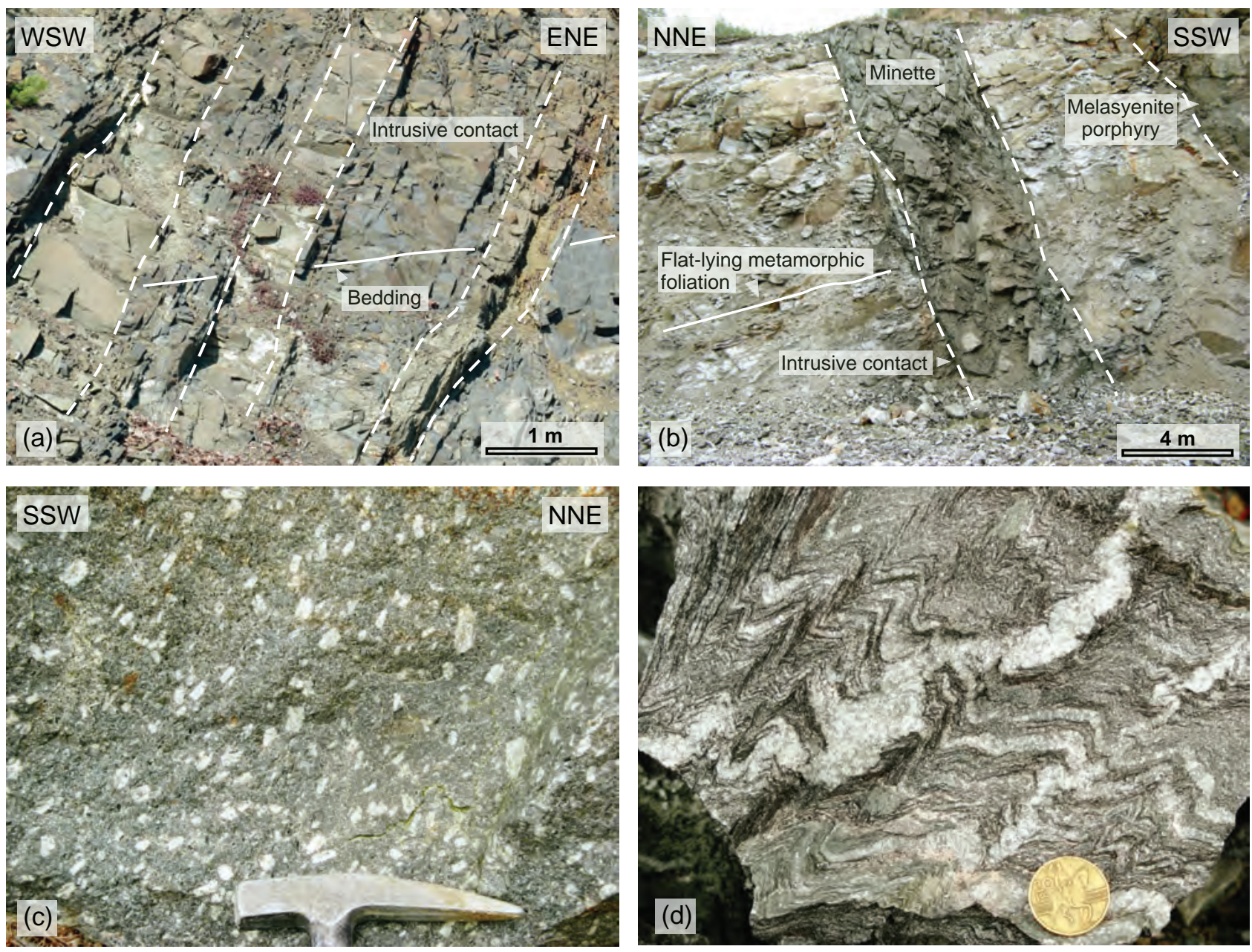

Fig. 3 Field photographs to show intrusive relationships of the dykes to host metamorphic rocks and fabric patterns. a - Originally steep discordant intrusive contacts between several kersantite dykes and host Neoproterozoic sequences of the Teplá-Barrandian Zone (Dobřís). b - Subparallel $\sim \mathrm{E}-\mathrm{W}$ trending steeply dipping ultrapotassic dykes (minette and syenite porphyry) which are discordant to regional metamorphic foliation in the host migmatite of the western Moldanubian Zone (Nihošovice). c - Magmatic (flow) foliation in syenite porphyry dyke defined by planar preferred orientation of K-feldspars (Nihošovice). Hammer for scale. d - Folded metamorphic foliation (compositional banding) in migmatites of western Moldanubian Zone which is discordantly intruded by the dyke-swarm (Nihošovice). Coin for scale.

2013), respectively. Rapid exhumation and cooling of the lower- to mid-crustal level at 343 to 337 Ma was associated with formation of one of the largest calc-alkaline and (ultra-) potassic lamprophyre dyke-swarms in the Central European Variscides (e.g. Žežulková 1982; Holub et al. 1995, 1997b, 2012; Janoušek and Holub 2007).

\subsection{Central Bohemian Dyke Swarm}

The Central Bohemian Dyke Swarm (Fig. 2) has been emplaced predominantly into older magmatic units of the CBPC, but also into adjacent parts of the Teplá-Barrandian a Moldanubian zones (Žežulková 1982; Holub et al. 1997b, 2012). The composition of these dykes varies from mafic to felsic and from calc-alkaline (spessartites, kersantites, gabbrodiorite to granodiorite porphyries) to (ultra)-potassic (minettes, vaugnerites and melasyenite to melagranite porphyries). The latter dykes reveal geo- chemical similarities to the (ultra-) potassic (durbachitic) plutonic rocks (Holub 1997; Holub et al. 1997b).

The overall occurrence of the Central Bohemian Dyke Swarm defines a rectangle $c .115 \mathrm{~km}$ long stretched approximately in the NNE-SSW direction from northeastern flank of the CBPC to its southwestern tip (Fig. 2).

The calc-alkaline spessartite to gabbrodiorite dykes were emplaced mainly into the oldest granitoids of the CBPC (medium-K calc-alkaline Sázava Pluton) and also into the adjacent upper-crustal Teplá-Barrandian Zone (Fig. 2). The average thickness of these dykes is $\sim 1$ to 6 meters. Prevailing intrusive contacts are steep and mostly discordant with respect to the regional fabrics in host rocks (Fig. 3a). The orientation of the dykes is mainly E-W to NW-SE; rarely, also NE-SW or N-S trending intrusive contacts have been observed.

All the (ultra-) potassic dykes (minettes, vaugnerites and melasyenite to melagranite porphyries) were emplaced 
Magnetic fabrics of lamprophyres and related rocks, Bohemian Massif

Tab. 1 Dykes of lamprophyres and related rocks investigated (location and geological characteristics)

\begin{tabular}{|c|c|c|c|c|c|c|c|c|}
\hline Latitude & Longitude & $\begin{array}{l}\text { Locality } \\
\text { No. }\end{array}$ & $\begin{array}{l}\text { Locality } \\
\text { Name }\end{array}$ & Rock Type & Host Unit & Thickness & Orientation & Mesoscopic fabric \\
\hline 49.80185 & 14.20024 & ZR-1 & Dobříšs & Kersantite & $\begin{array}{c}\text { TBZ } \\
\text { Proterozoic Unit }\end{array}$ & $8.5 \mathrm{~m}$ & $\begin{array}{c}\text { NW-SE } \\
41 / 86,60 / 85 \text {, }\end{array}$ & no apparent \\
\hline 49.72086 & 14.01888 & ZR-2 & $\begin{array}{l}\text { Příbram - Trhové } \\
\text { Dušníky }\end{array}$ & Spessartite & $\begin{array}{c}\text { TBZ } \\
\text { Proterozoic Unit }\end{array}$ & $\sim 3 \mathrm{~m}$ & $\begin{array}{c}\text { NE-SW } \\
145 / 48\end{array}$ & no apparent \\
\hline 49.62877 & 14.05309 & ZR-3 & Milín - Kojetín & Spessartite & $\begin{array}{c}\text { CBPC } \\
\text { Marginal granite }\end{array}$ & $1.5 \mathrm{~m}$ & $\begin{array}{c}\text { NW-SE } \\
47 / 88\end{array}$ & no apparent \\
\hline 49.62538 & 14.05157 & ZR-4 & Milín W & Minette & $\begin{array}{c}\text { CBPC } \\
\text { Marginal granite }\end{array}$ & $1.7 \mathrm{~m}$ & $\begin{array}{c}\text { NW-SE } \\
60 / 85,63 / 79\end{array}$ & contact parallel \\
\hline 49.62688 & 14.05196 & ZR-5 & Milín E & Minette & $\begin{array}{c}\text { CBPC } \\
\text { Marginal granite }\end{array}$ & $0.45 \mathrm{~m}$ & $\begin{array}{c}\text { N-S } \\
90 / 89\end{array}$ & no apparent \\
\hline 49.54967 & 14.10815 & ZR-6 & Zalužany - Kozárovice & Minette & $\begin{array}{c}\text { CBPC } \\
\text { Blatná Pluton }\end{array}$ & $1.60 \mathrm{~m}$ & $\begin{array}{c}\text { W-E } \\
170 / 85\end{array}$ & no apparent \\
\hline 49.86089 & 14.51760 & KV-KU & Kamenný Újezdec & $\begin{array}{l}\text { Syenite } \\
\text { porphyry }\end{array}$ & $\begin{array}{c}\text { CBPC } \\
\text { Sázava Pluton }\end{array}$ & $\sim 8 \mathrm{~m}$ & $\begin{array}{c}\text { WNW-ESE } \\
27 / 62\end{array}$ & contact parallel \\
\hline 49.84214 & 14.69152 & KV-PS & Poříčí nad Sázavou & Minette & $\begin{array}{c}\text { CBPC } \\
\text { Sázava Pluton }\end{array}$ & $4 \mathrm{~m}$ & $\begin{array}{c}\text { NW-SE } \\
51 / 88,206 / 86\end{array}$ & contact parallel \\
\hline 49.40026 & 13.70356 & $\mathrm{KV}-\mathrm{C}$ & Újezd u Chanovic & Minette & $\begin{array}{c}\text { CBPC } \\
\text { Blatná Pluton }\end{array}$ & $8 \mathrm{~m}$ & $\begin{array}{c}\text { W-E } \\
186 / 81\end{array}$ & no apparent \\
\hline 49.32149 & 13.53378 & KV-NH & $\begin{array}{l}\text { Nalžovské Hory - } \\
\text { Letovy }\end{array}$ & $\begin{array}{l}\text { Syenite } \\
\text { porphyry }\end{array}$ & $\begin{array}{c}\text { CBPC } \\
\text { Blatná Pluton }\end{array}$ & $7 \mathrm{~m}$ & $\begin{array}{c}\text { WNW-ESE } \\
194 / 87\end{array}$ & contact parallel \\
\hline 49.18331 & 13.85323 & KV-Ni & Nihošovice & $\begin{array}{l}\text { Syenite } \\
\text { porphyry }\end{array}$ & Moldanubian Zone & $21 \mathrm{~m}$ & $\begin{array}{c}\text { W-E } \\
189 / 82\end{array}$ & magmatic foliation \\
\hline 49.38048 & 14.05131 & KV-Ma & Malčice & $\begin{array}{l}\text { Syenite } \\
\text { porphyry }\end{array}$ & $\begin{array}{c}\text { CBPC } \\
\text { Blatná Pluton }\end{array}$ & $6 \mathrm{~m}$ & $\begin{array}{c}\text { W-E } \\
7 / 72,358 / 84\end{array}$ & magmatic foliation \\
\hline 49.88826 & 14.75448 & KV-Se & Senohraby & Spessartite & $\begin{array}{c}\text { TBZ } \\
\text { Proterozoic Unit }\end{array}$ & $2.5 \mathrm{~m}$ & $\begin{array}{l}\text { NW-SE } \\
\text { not known }\end{array}$ & no apparent \\
\hline
\end{tabular}

TBZ - Teplá Barrandian Zone; CBPC - Central Bohemian Plutonic Complex

into partly exhumed mid-crustal paragneisses to migmatites of the WMZ and into older intrusive bodies of the CBPC (medium-K calc-alkaline Sázava and high-K calcBlatná suites dated at 354 and $346 \mathrm{Ma}$, respectively), but not into ultrapotassic plutons and younger intrusions of the CBPC c. 340-335 Ma old (Holub et al. 1997).

The individual melasyenite to melagranite porphyries (U-Pb zircon age $337.87 \pm 0.21 \mathrm{Ma}$; Kubínová et al. 2017) are oriented W-E to WNW-ESE and are nearly vertical or steeply dipping southwards (Fig. 3b). Dyke thickness varies from 5 to $20 \mathrm{~m}$, the lengths are often limited to less than $1-2 \mathrm{~km}$, perhaps due to segmentation of dykes by younger faults. Horizontal distances between parallel porphyry dykes vary considerably being about $0.5-1.0 \mathrm{~km}$ in districts with the highest density of dyking. These dykes show well-developed magmatic (flow) foliation, which is defined by planar preferred orientation of K-feldspar phenocrysts (Fig. 3c). External contacts of porphyry dykes are sharp and generally discordant to folded metamorphic foliations of host gneisses and migmatites (Fig. 3d). At southern margin of the CBPC, dykes of the same rock type are discordant to the fabric of the host granodiorites.

Minettes are commonly parallel to porphyry dykes (Fig. 3b) and their field relations are comparable. However, owing to their apparently lower magma viscosity, minette dykes are generally much narrower, frequently with offshoots and strings. The most frequent thickness ranges $0.5-1.5 \mathrm{~m}$, only rarely exceed- ing 2 meters. Their intrusive contacts are mostly sharp and discordant with respect to regional fabrics and older plutons. All ultrapotassic dykes have similar trend, $\sim \mathrm{W}(\mathrm{WNW})$ to $\mathrm{E}(\mathrm{ESE})$, with steeply dipping intrusive contacts. Repeated intrusions of magma portions from dykes of almost uniform strikes exemplify the long-lasting uniformity of the regional stress field with the least compressional stress oriented roughly $\mathrm{N}(\mathrm{NNE})-\mathrm{S}(\mathrm{SSW})$ thus allowing a limited extension in this direction.

\section{Analytical techniques}

The oriented specimens were drilled in 14 selected dykes of the Central Bohemian Dyke Swarm using portable drilling machine and oriented using geological compass mounted on special orientating fixture (see Tab. 1).

The AMS was measured with the KLY-3S (Jelínek and Pokorný 1997) and MFK1-FA kappabridges (Pokorný et al. 2011) in the driving field $425 \mathrm{~A} / \mathrm{m}$ peak at the operating frequencies $920 \mathrm{~Hz}$ and $976 \mathrm{~Hz}$, respectively, using the 3D rotator in the latter instrument (Studýnka et al. 2014), and the results were calculated by the SAFYR program (version 5).

The mean bulk susceptibility $\left(K_{m}\right)$, degree of AMS $(P)$ and shape of the AMS ellipsoid $(T)$ are defined as follows (Nagata 1961; Jelínek 1981) 

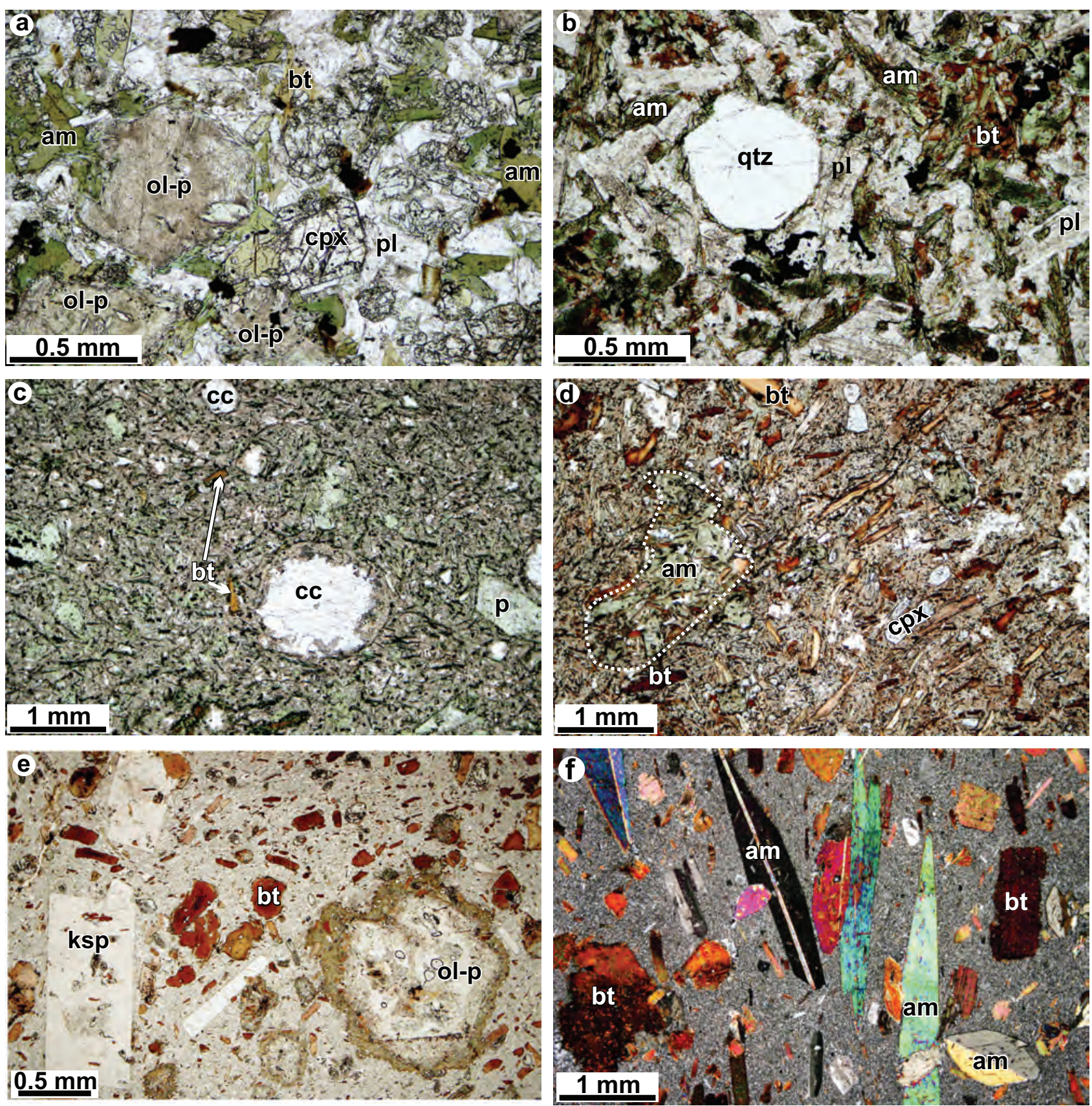

Fig. 4 Selected photomicrographs from rocks of the Central Bohemian dyke swarm (a-e: PPL, f: XPL). a - Kersantite/spessartite dykes, Dobřís (ZR-1) with pseudomorphs of talc after olivine (ol-p), clinopyroxene (cpx), amphibole (am), plagioclase (pl) and biotite (bt). The black grains are opaque phases. Note the hexagonal talc pseudomorphs that are partly overgrown by amphibole. b - Spessartite from Milín (dyke ZR-3) with porphyric grains of quartz (qtz) in plagioclase, amphibole and biotite matrix. Amphibole is mostly overgrown by biotite. Note the opaque minerals (black) following a zone from upper-right to lower-left corner of the image. c - Minette from Milín (dyke ZR-5) with vesicles filled by calcite (cc). The angular grains are pseudomorphs (p) of chlorite with calcite after clinopyroxene. The thin dark grains are biotite replaced by chlorite with opaque phases. The matrix consists of chlorite, calcite, and opaque phases with relicts of feldspars. d - Minette from Zalužany (dyke ZR-6) with biotite, amphibole (dashed field labelled am) and clinopyroxene in the fine-grained, almost glassy matrix. The white irregular grains are K-feldspar and quartz. Note that biotite, amphibole and some clinopyroxene grains show orientation in one direction. $\mathbf{e}$ - Syenite porphyry from Nihošovice (dyke KV-Ni) with phenocrysts of K-feldspar (ksp) and biotite as well as pseudomorphs of talc after olivine. The matrix consists of K-feldspars, biotite and quartz. f - Syenite porphyry from Nihošovice with almost parallel phenocrysts of amphibole and biotite, in fine-grained matrix.

$$
\begin{aligned}
& K_{m}=\left(k_{1}+k_{2}+k_{3}\right) / 3 \\
& P=k_{1} / k_{3} \\
& T=\left(2 \eta_{2}-\eta_{1}-\eta_{3}\right) /\left(\eta_{1}-\eta_{3}\right)=2 \ln F / \ln P-1
\end{aligned}
$$

where $k_{1} \geq k_{2} \geq k_{3}$ are the principal susceptibilities, $\eta_{1}=$ $\ln k_{1}, \eta_{2}=\ln k_{2}, \eta_{3}=\ln k_{3}$.

The statistical evaluation of the AMS at individual localities was made using the ANISOFT program package 
(Jelínek 1978; Hrouda et al. 1990; Chadima and Jelínek 2008). The orientation of magnetic foliations and magnetic lineations, the respective mean directions and corresponding confidence areas are presented in equal-area projections on the lower hemisphere in the dyke coordinate system (dyke was rotated about its strike to vertical position and about the vertical axis to $\mathrm{N}-\mathrm{S}$ position).

The magnetic minerals carrying the AMS were investigated through the Maximum Theoretical Paramagnetic Susceptibility (MTPS) method (Aydin et al. 2007) and through the susceptibility variation with magnetizing field, with operating frequency, and with temperature. The susceptibility was measured in the magnetizing fields ranging from $2 \mathrm{~A} / \mathrm{m}$ to $700 \mathrm{~A} / \mathrm{m}$ at the operating frequency $976 \mathrm{~Hz}$ using the automated mode of the MFK1-FA Kappabridge. It can be concisely characterized by the $V_{\mathrm{m}}$ parameter defined as follows (Hrouda et al. 2006):

$$
V_{\mathrm{m}}=100\left(k_{\max }-k_{\min }\right) / k_{\min }[\%]
$$

where $k_{\max }$ and $k_{\min }$ are the maximum and minimum susceptibilities, respectively, obtained during one measuring run. The susceptibility variation with operating frequency was investigated at the frequencies $976 \mathrm{~Hz}$ and 15,616 $\mathrm{Hz}$ in the driving field $200 \mathrm{~A} / \mathrm{m}$. It can be represented quantitatively by the commonly accepted percentage loss of susceptibility (Dearing et al. 1996):

$$
X_{\mathrm{FD}}=100\left(k_{\mathrm{LF}}-k_{\mathrm{HF}}\right) / k_{\mathrm{LF}}[\%]
$$

where $k_{\mathrm{LF}}$ and $k_{\mathrm{HF}}$ are susceptibilities measured at low and high frequencies, respectively. The susceptibility variation with temperature was measured on coarsely powdered pilot specimens at -194 to $0^{\circ} \mathrm{C}, 25$ to $700^{\circ} \mathrm{C}$ (heating curve) and back to $40^{\circ} \mathrm{C}$ (cooling curve), and then again between -194 and $0^{\circ} \mathrm{C}$, using the CS-L Cryostat, CS-4 Furnace (Parma et al. 1993) and the MFK1-FA Kappabridge. The Curie temperatures were determined using the Petrovský and Kapička (2006) method looking for the beginning of the paramagnetic hyperbola exactly at the Curie temperature.

\section{Petrology}

The selected 14 dykes of lamprophyres and related rocks show a compositional range from calc-alkaline to (ultra) potassic. Most dykes are represented by one rock type, but texturally they may change from relatively coarse-grained in the core to fine-grained or even to aphanitic variety at the contact with the host lithology. In one case (locality of Dobrríš), a composite dyke, formed by symmetric zones of three rock types, is present (Holub 2003). Based on modal composition and textures, the rocks from selected dykes can be classified into four groups as outlined below.

\subsection{The composite dyke from Dobríšs}

The overall thickness of the dyke is about $8.5 \mathrm{~m}$ and it consists of three symmetric zones. The dyke is dominated by the outermost kersantite (Fig. 4a) that is separated from c. $1 \mathrm{~m}$ thick axial hornblendite zone by a thin transitional zone of spessartite composition. In general, there are gradual transitions between individual zones and the grain size of mafic minerals increases inwards. The whole dyke is characterized by ocellar texture, with the spherical ocelli filled by carbonate and partly by quartz. In addition to clinopyroxene phenocrysts with spinel inclusions, the kersantite contains pseudomorphs of talc after olivine. Spinel is also present in the talc pseudomorphs. The matrix is fine-grained and consists of plagioclase, clinopyroxene, biotite and small amounts of quartz, carbonate and accessory apatite and opaque phases. In addition to high amphibole content, the hornblendite contains pseudomorphs after olivine, clinopyroxene, plagioclase, biotite and spinel. The amphibole is magnesio-hornblende and shows optical zoning with green-brown cores and green rims.

\subsection{Spessartite}

It is a dark-grey, medium- to fine-grained rock dominated by amphibole, biotite and plagioclase with minor alkali feldspar, secondary chlorite, actinolite, carbonate and quartz (Fig. 4b). Spessartite from Dobříš contains also diopsidic augite and pseudomorphs of talc after olivine. Amphibole forms euhedral prismatic phenocrysts up to $4 \mathrm{~mm}$ long. It is magnesio-hornblende-tschermakite that is partly replaced by actinolite, chlorite or overgrown by biotite. The matrix is formed by biotite, plagioclase and amphibole. Biotite is very fine-grained and occurs in the matrix. Apatite, Fe-Ti oxides and chromium spinel are common accessory phases. Spessartite from Milín (Fig. 4b) contains xenocrysts of quartz within plagioclase, amphibole and biotite matrix. The quartz appears as monocrystals but it forms round grains similar to vesicles.

\subsection{Minette}

Minette is a dark-grey, fine-grained and porphyritic rock with hypidiomorphic texture. The grain size usually decreases towards the outer contact with the host rocks, where it becomes glassy or more aphanitic in appearance. Olivine and/or clinopyroxene phenocrysts are typically subhedral to euhedral and $c .1 \mathrm{~mm}$ in size. Olivine phenocrysts are replaced by talc. The matrix consists of biotite (phlogopite), alkali feldspar, amphibole, and small amounts of albite and calcite. In cases, the minettes have amygdaloidal texture; the vesicles are filled by calcite (Fig. 4c). Biotite and amphibole may define magmatic foliation in the rock (Fig. 4d). Apatite, titanite and $\mathrm{Fe}-$ 


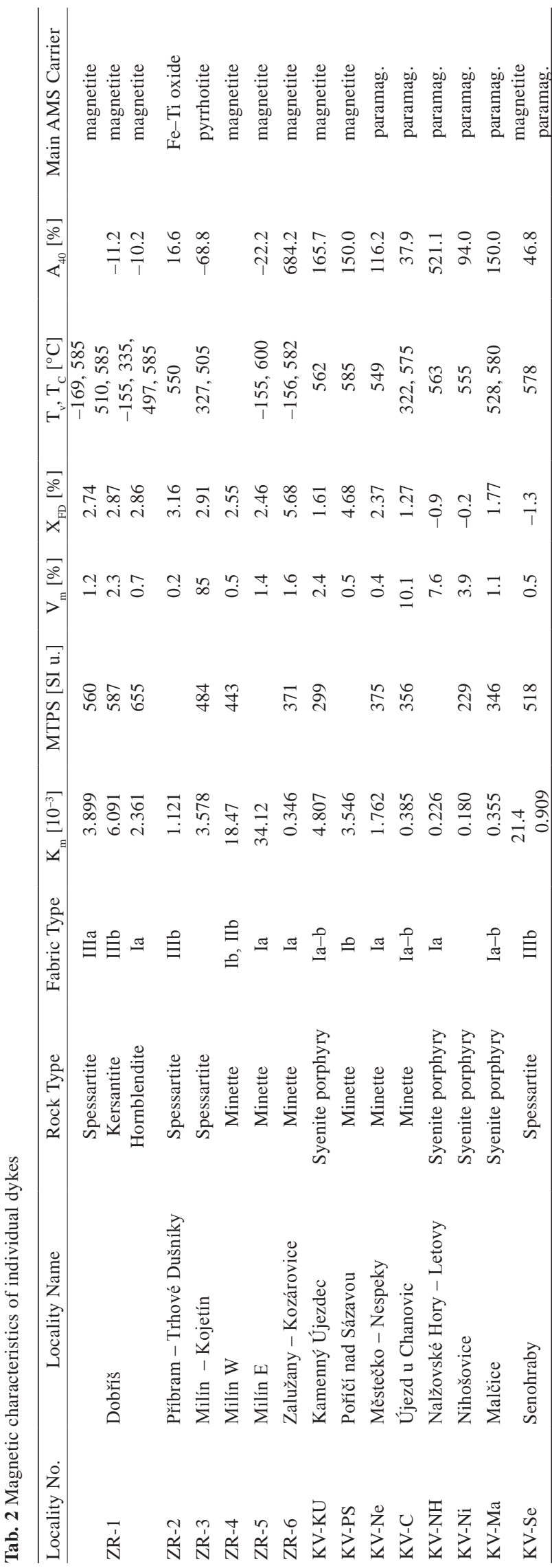

Ti oxides can occur as accessory phases. Amphibole is actinolite and it is mostly formed by replacement of clinopyroxene.

\subsection{Quartz syenite to melagranite porphyry}

This is a grey, fine-grained porphyritic rock dominated by plagioclase or K-feldspar with biotite and amphibole. In cases, it may contain pseudomorphs of talc after olivine, rimmed by biotite (Fig. 4e). Euhedral to subhedral Kfeldspar phenocrysts are up to $6 \mathrm{~mm}$ in size. Amphibole occurs as euhedral, prismatic phenocrysts up to $5 \mathrm{~mm}$ long (Fig. 4f). It is usually actinolite, which formed by replacement of clinopyroxene or possibly also of primary hornblende. The feldspar laths and prismatic amphibole phenocrysts show locally a magmatic flow alignment. The matrix is formed by plagioclase and/or alkali feldspar, biotite, occasionally amphibole and rare quartz. Accessory phases are Fe-Ti oxides and apatite.

\section{Whole rock geochemistry}

Based on the TAS diagram (Le Bas et al. 1986), the above-mentioned four groups range from basalt, through basaltic trachyandesite to trachyte/trachydacite (Fig. 5a). The mafic varieties (hornblendite, spessartite and kersantite) show calc-alkaline affinity, while the minette and quartz syenite porphyry belong to high-K calc-alkaline series or, more commonly, shoshonite series (Fig. 5b). A continuous compositional change exists in the $\mathrm{MgO}$, $\mathrm{FeO}$ and $\mathrm{CaO}$ variations, where all three oxides decrease from hornblendite and spessartite/kersantite to minette and quartz syenite porphyry (Fig. 5c-d). Both $\mathrm{FeO}$ and $\mathrm{CaO}$ show positive correlation with $\mathrm{MgO}$.

\section{Magnetic mineralogy}

The mean volume susceptibility of the dykes investigated is variable, ranging from the order of $10^{-4}$ to the order of $10^{-2}$ (Fig. 6, Tab. 2). The MTPS method, which calculates the rock paramagnetic susceptibility from the Fe and Mn contents obtained from the whole-rock chemical analyses, shows that the contribution of paramagnetic minerals to the whole-rock susceptibility is relatively low, ranging from $0.2 \times 10^{-3}$ to $0.7 \times 10^{-3}$. Consequently, in weakly magnetic dykes $\left(K_{m}<0.7 \times 10^{-3}\right)$, the susceptibility can be significantly affected by paramagnetic minerals, while in the dykes with higher susceptibility the ferromagnetic minerals play a more important, sometimes even dominant, role.

The susceptibility variation with field is either nondetectable practically (Fig. 7a), very weak (Fig. 7b), or even very strong (Fig. 7c). The mean values of the $V_{\mathrm{m}}$ 

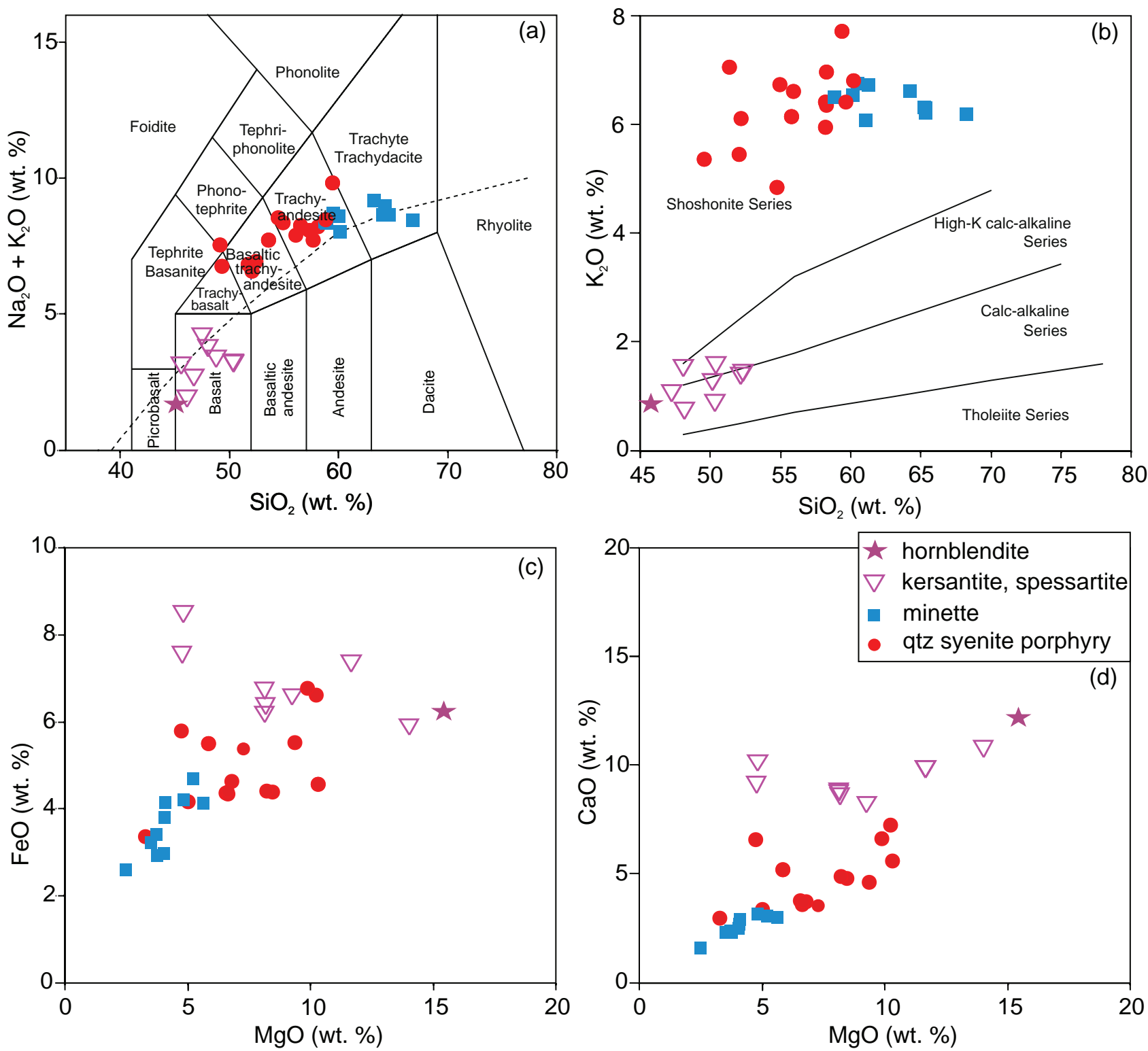

Fig. 5 Geochemical classification of lamprophyres and related rocks: a - Total alkali-silica (TAS) classification diagram (Le Bas et al. 1986); b $-\mathrm{K}_{2} \mathrm{O}$ vs. $\mathrm{SiO}_{2}$ (wt. \%) diagram (according to Peccerillo and Taylor 1976); c - FeO vs. MgO (wt. \%); d - CaO vs. MgO (wt. \%). The major-element data have been recalculated to 100 wt. \% on a volatile-free basis. Based on data from Holub et al. (2007, 2009, 2010), Kubínová et al. (2017) and unpublished data of F.V. Holub.

parameter for individual dykes are presented in Tab. 2. Among ferromagnetic minerals sensu lato, pure magnetite shows virtually field-independent susceptibility, while in titanomagnetite, pyrrhotite and hematite the susceptibility may be clearly field-dependent even in low fields used in common AMS meters (e.g., Worm et al. 1993; Jackson et al. 1998; Hrouda 2002, 2006; de Wall and Nano 2004). From this point of view, none or very weak susceptibility variation of most specimens investigated may indicate presence of more or less pure magnetite. The susceptibility vs. field curves of the specimens from the locality ZR-3 showing strong susceptibility increase with field resembling curves of some types of pyrrhotite (cf. Hrouda et al. 2006, 2009). This conclusion is supported by very strong variation of out-of-phase susceptibility with field (Fig. 7d). The out-of-phase susceptibility originates in materials in which, if measured in alternating magnetic field, the magnetic response delays behind the magnetizing field. The susceptibility may then be formally resolved into the component that is in-phase (almost exclusively used in rock magnetism) and that which is out-of-phase with respect to magnetizing field. The strong field variation of the out-of-phase component is characteristic of minerals with wide hysteresis loop such as pyrrhotite.

The grain size of ferromagnetic sensu lato minerals can be assessed, at least partially, through frequency-de- 


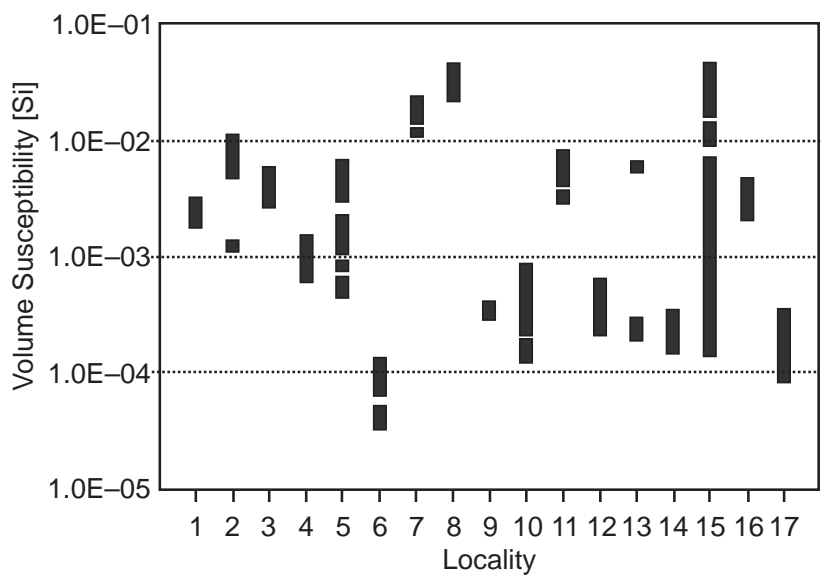

Fig. 6 Point diagram of bulk magnetic susceptibility in individual dykes. (1) ZR-1 hornblendite, (2) ZR-1 kersantite, (3) ZR-1 spessartite, (4) ZR-2 spessartite, (5) ZR-3 spessartite, (6) ZR-3 host granite, (7) ZR-4 minette, (8) ZR-5 minette, (9) ZR-6 minette, (10) KV-C minette, (11) KV-KU syenite porphyry, (12) KV-Ma syenite porphyry, (13) KV-Ne minette, (14) KV-NH syenite porphyry, (15) KV-Se spessartite, (16) KV-PS minette, (17) KV-Ni syenite porphyry.

pendent susceptibility. Namely, the frequency-dependent susceptibility is effectively zero in multi-domain (MD) and single-domain (SD) grains of magnetite (titanomagnetite) as well as in its ultra-fine superparamagnetic (SP) grains (e.g. Dearing et al. 1996; Hrouda 2011). On the other hand, it can be clearly non-zero in magnetically
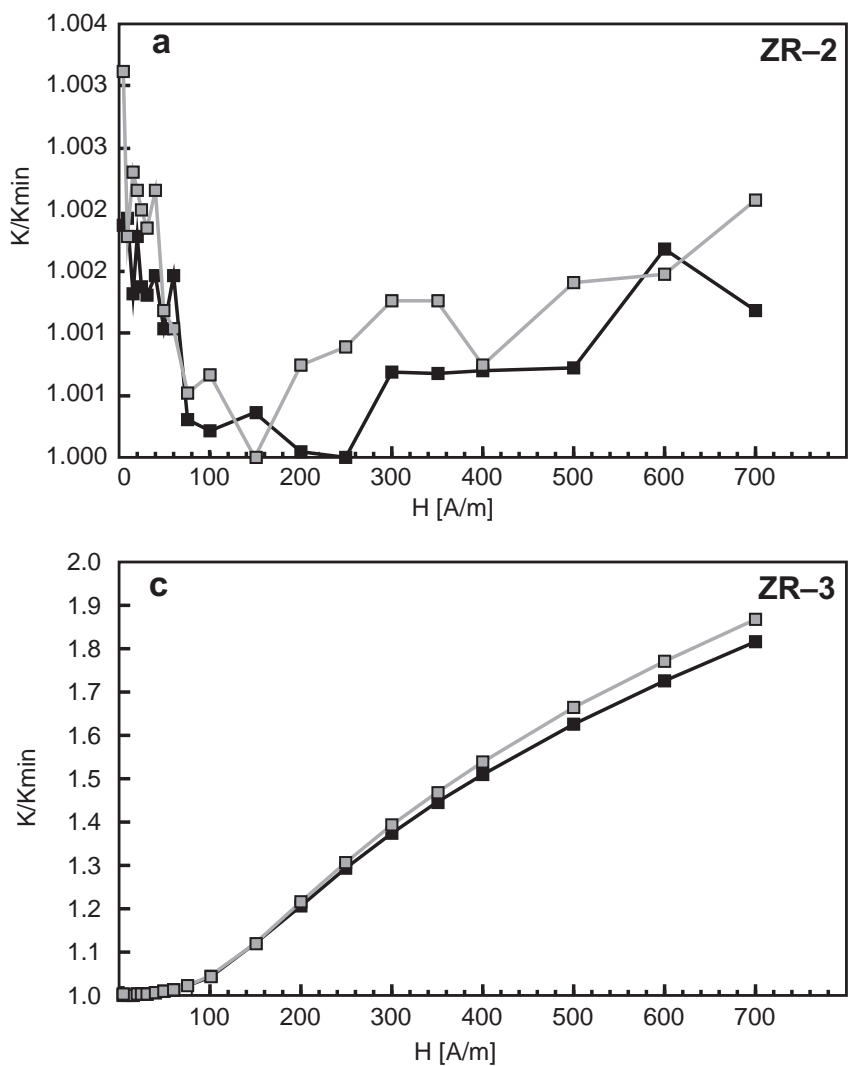

viscous grains that are on the transition from SP state to SD state. The $X_{\mathrm{FD}}$ parameter in the dykes investigated ranges from $2.5 \%$ to $6.5 \%$. If we realize that the detection limit of the $X_{\mathrm{FD}}$ parameter is less than 1\% (Hrouda and Pokorný 2011) and the $X_{\mathrm{FD}}$ parameter is mostly less than 15\% (Dearing et al. 1996; Eyre 1997; Worm 1998), it is obvious that the dykes investigated contain magnetic grains that are on the transition from SP to SD states in non-negligible amounts. Assuming that the magnetic particles show continuous size distribution, it is likely that the rocks investigated contain also SD particles.

The heating curves mostly show one acute susceptibility decrease due to Curie temperature at $500-600^{\circ} \mathrm{C}$ (Figs $8 \mathrm{a}-\mathrm{d})$. The Curie temperatures that are near $585^{\circ} \mathrm{C}$ correspond to those of magnetite, whose presence is confirmed by the susceptibility decrease at $c .-155^{\circ} \mathrm{C}$ at Verwey transition, which is typical of relatively pure magnetite (Dunlop and Özdemir 1997). The Curie temperatures less than $550^{\circ} \mathrm{C}$ probably indicate Ti-richer Fe-Ti oxides. In the dyke ZR-1, there are three susceptibility decreases on the heating curves, at $335^{\circ} \mathrm{C}, \mathrm{c} .500^{\circ} \mathrm{C}$, and $585^{\circ} \mathrm{C}$ (Fig. 8b). The last temperature probably points to magnetite, the second may reflect the presence of titanomagnetite. The susceptibility decrease at $335^{\circ} \mathrm{C}$ may indicate $\mathrm{Fe}-\mathrm{Ti}$ oxide with relatively high content of Ti or pyrrhotite. As the Curie temperature of pyrrhotite is usually very near $325^{\circ} \mathrm{C}$, the first interpretation seems
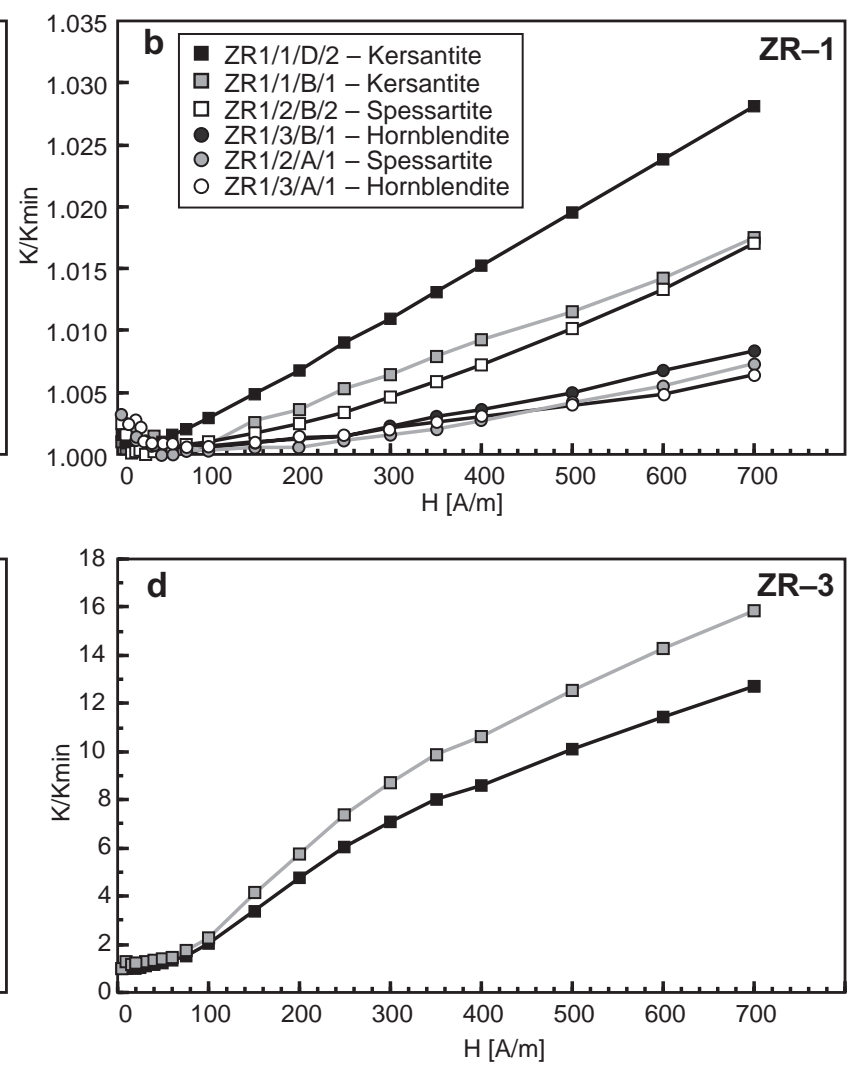

Fig. 7 Examples of variation of bulk susceptibility $K / K_{\min }$ with measuring field $H$. 

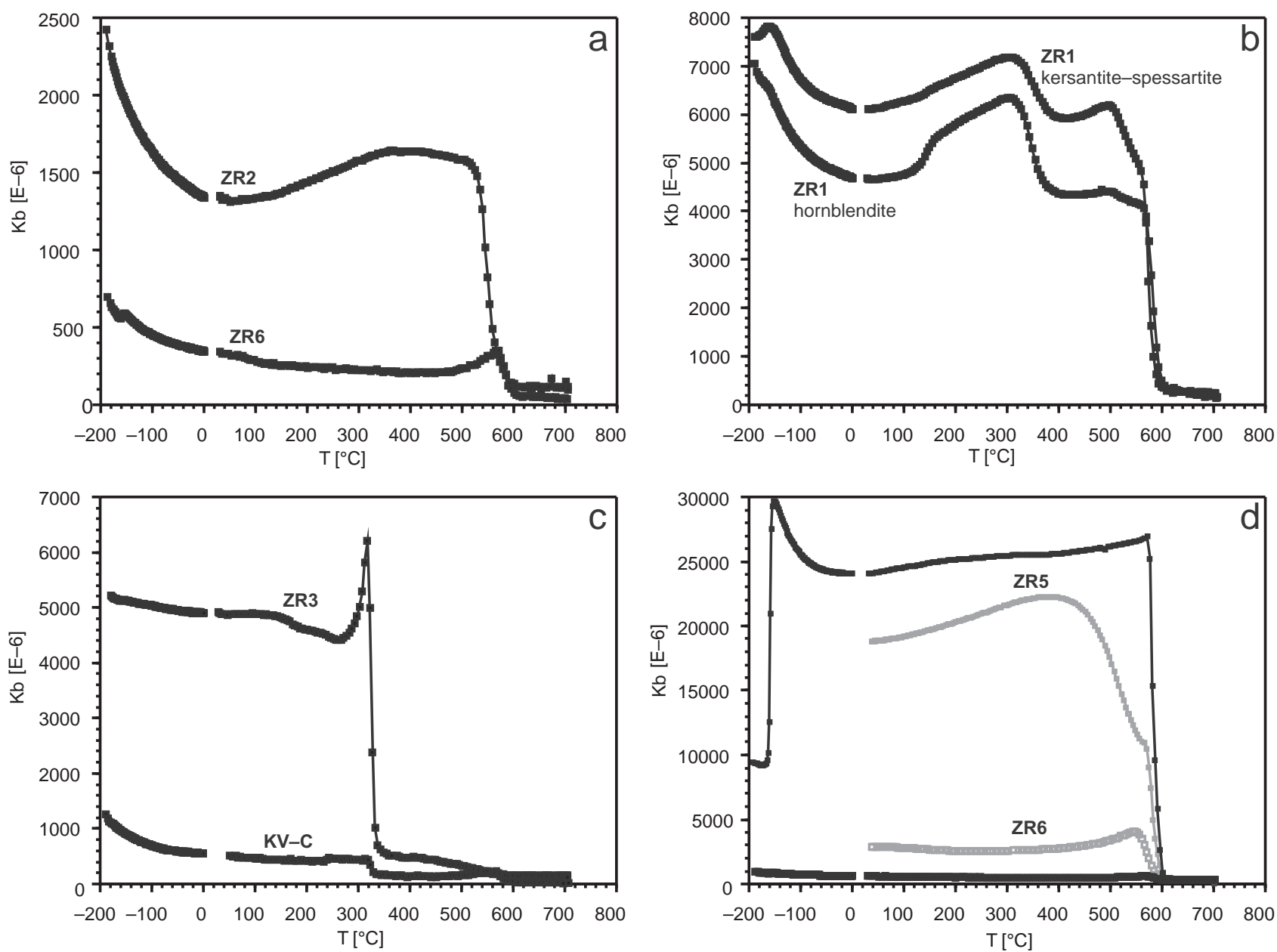

Fig. 8 Temperature variation of susceptibility for pilot specimens. In black are heating curves, in grey cooling curves.

more likely. It is interesting that the curves of kersantite/ spessartite and hornblendite are very similar thus supporting the observation of Holub (2003) of gradual transitions between individual rock types within this dyke. In the dykes ZR-3 and KV-C, the heating susceptibility vs. temperature curves show the most conspicuous and acute susceptibility decrease due to Curie temperature at 327 and $322^{\circ} \mathrm{C}$, respectively, and very minor decreases at 505 and $575^{\circ} \mathrm{C}$, respectively (Fig. 8c). The former undoubtedly indicates pyrrhotite and the latter probably $\mathrm{Fe}-\mathrm{Ti}$ oxides to magnetite.

The cooling curves may run higher than the heating ones (see Fig. 8d, Tab. 2). This difference indicates that the assemblage of magnetic minerals is rather unstable and prone to activating various magnetic phases due to specimen heating. This may for instance result from post-magmatic alterations during magma cooling or from the effect of epigenetic fluids. On the other hand, the cooling curves may also run lower than the heating ones (see Fig. 8d, Tab. 2). This may indicate dissolution of the earlier separated phases resulting in the creation of a less magnetic phase.
In weakly magnetic specimens, the most conspicuous feature of the heating curves is paramagnetic hyperbola (for example see the low temperature segment of the curve KV-C in Fig. 8c). The paramagnetic susceptibilities determined through resolution of the susceptibility vs. temperature curve into paramagnetic hyperbola and ferromagnetic straight line using the method by Hrouda (1994) are mostly in the order of $10^{-4}$, thus being of the same order as those obtained by the MTPS method.

Magnetite is dominant contributor to the rock susceptibility and AMS in strongly magnetic dykes ZR-1, ZR-4, ZR-5, KV-KU, KV-PS, and partially also KV-Ne. As the magnetite AMS is controlled by its grain shape, the rock AMS is determined by the magnetite grain-shape preferred orientation. Even though there may be some other magnetic phases in the above dykes, their contributions to the rock susceptibility are relatively low. In the dyke ZR-3, the AMS is dominantly carried by pyrrhotite preferentially oriented by mineral lattice. In weakly magnetic dykes, the AMS signal is often dominated by paramagnetic mafic silicates; sometimes the magnetic fabric is composite, due to both paramagnetic minerals and $\mathrm{Fe}-\mathrm{Ti}$ oxides. 


\section{Magnetic fabrics}

\subsection{Dobrríš composite dyke}

The degree of AMS is very low in all rock types (Fig. 9a). The shape of the AMS ellipsoid ranges from prolate to oblate in kersantite, from neutral (on the transition between prolate and oblate) to moderately oblate in spessartite and from moderately prolate to moderately oblate in hornblendite (Fig. 9).

Both the magnetic foliations and lineations are always relatively well defined. In the central hornblendite, the magnetic foliation is approximately parallel to the dyke plane, while the magnetic lineation is horizontal and also parallel to the dyke plane (Fig. 9b). This fabric corresponds to the Type Ia. In kersantite, the magnetic foliation is sometimes oblique to the dyke plane but in the most specimens vertical and perpendicular to the dyke plane; the magnetic lineation is mostly perpendicular to the dyke (Fig. 9c). The magnetic fabric of the most specimens corresponds to the Type IIIb. In spessartite, both the magnetic foliations and magnetic lineations are virtually horizontal, approximately perpendicular to the dyke plane (Type IIIa; see Fig. 9d).

The fact that the magnetic fabrics are conspicuously different in the individual rock types excludes a possibility of post-magmatic origin and can be interpreted in terms of magma flow. The Type Ia magnetic fabric

a) ZR-1 - Dobříš

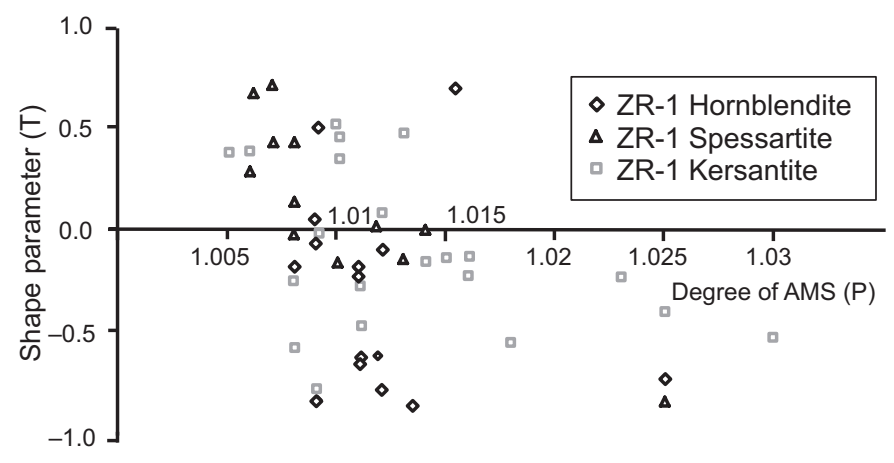

b) ZR-1 Hornblendite

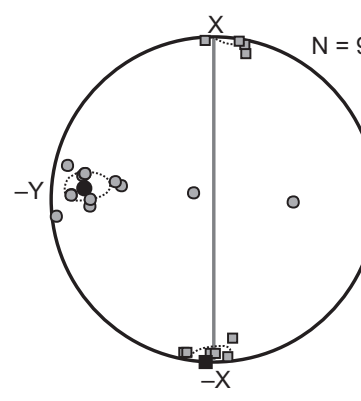

c) ZR-1 Kersantite

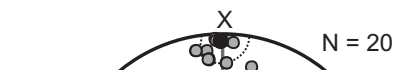

d) ZR-1 Spessartite

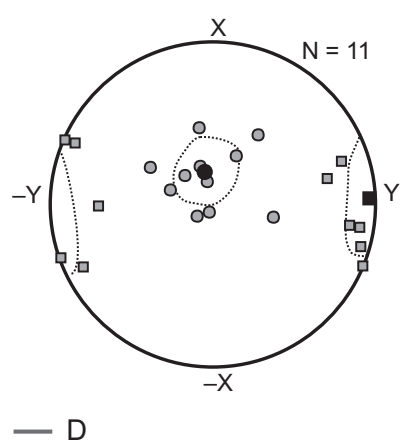

in central hornblendite that is the most frequent in the intermediate and mafic dykes the world over, evidently indicates relatively free flow during which the magnetic minerals orientate parallel with their larger surfaces to the dyke and with their longer dimensions parallel to the magma flow. The horizontal flow direction indicates that the hornblendite part of the dyke was not fed by vertical flow along the entire dyke length, but only locally and then the magma propagated through horizontal flow.

In kersantite and spessartite dykes, the magnetic foliations are perpendicular to the dyke, being vertical in kersantite and horizontal in spessartite, and the magnetic lineations are also perpendicular to the dyke and approximately horizontal. These fabric types belong to the most controversial Types III $a$ and $b$, the origins of which are disputable. The magnetic foliation perpendicular to the dyke could indicate the magma movement mechanism hypothesized by Raposo and Ernesto (1995) for the Type II, i.e. compaction of a static magma column along the dyke in which the magnetic minerals reoriented with their larger surfaces perpendicular to the magma movement. If true, the magma movement would be horizontal in kersantite and vertical in spessartite. The origin of magnetic lineations perpendicular to the dyke is extremely difficult to explain. One explanation would be that of Rochette et al. (1991) ascribing this magnetic lineation to secondary processes such as hydrothermal alteration. The other assumes squeezing of some portions of magma due to the pressure of the other portions of magma resulting in thickening of the dyke and faint magma movement in the direction perpendicular to the dyke.

\subsection{Minette dykes}

The magnetic fabric of minette dykes was investigated at six localities. The degree of AMS is mostly very low, only in the $\mathrm{KV}$-C dyke it ranges from very low to moderately high (Fig. 10a). The shape of the AMS ellipsoid is mostly oblate, prolate one was found only in a few specimens in ZR-4 and $\mathrm{KV}-\mathrm{C}$ dykes (Fig. 10a). In each of the minette dykes investigated, the

Fig. 9 Pattern of the AMS in the composite dyke ZR-1 (Dobrířš). a - Magnetic anisotropy P-T plot. Orientations of magnetic lineations (squares) and magnetic foliation poles (circles): in hornblendite (b), kersantite (c) and spessartite (d). Equal-area projection on lower hemisphere. Ellipses represent confidence areas. 
magnetic foliation of either almost all (dykes ZR-5, ZR-6, $\mathrm{KV}-\mathrm{Ne}$ ) or at least majority of specimens (dykes ZR-4, $\mathrm{KV}-\mathrm{PS}, \mathrm{KV}-\mathrm{C}$ ) is near the dyke plane (Fig. 10b-g). Some dykes (ZR-4, KV-PS, KV-C) yielded also a few specimens with magnetic foliation at a large angle to the dyke plane, being sometimes even perpendicular. The magnetic lineation is roughly parallel to the dyke plane in all dykes, being virtually vertical in two (ZR-4, KV-PS), horizontal in three (ZR-5, ZR-6, KV-Ne), and ranging from vertical to horizontal in one (KV-C) of them (Fig. 10b-g).

The magnetic fabric in the majority of specimens corresponds to the Type Ia. This type evidently originates from relatively free flow during which the magnetic minerals orientate parallel with their larger surfaces to the dyke margins and with their longer dimensions parallel to the magma flow. The vertical orientation of magnetic lineation in the dykes ZR-4 and KV-PS indicate vertical magma flow. The horizontal magnetic lineations in the dykes ZR-5, ZR-6, $\mathrm{KV}$-Ne probably document that these dykes were fed by vertical flow only locally and then the magma propagated through horizontal flow. In some dykes, there are rare specimens with magnetic foliation roughly perpendicular to the dyke plane. They suggest that the magma movement need not be represented by free flow in the entire volume of the dyke, but could have been rather represented by compressive deformation in which the magnetic minerals reorient with their larger surfaces perpendicular to the magma movement. In the $\mathrm{KV}-\mathrm{C}$ dyke one can observe gradual transitions from one mechanism to the other.

\subsection{Quartz syenite to melagranite porphyry dykes}

The magnetic fabric of syenite porphyry dykes was investi-

Fig. 10 Pattern of the AMS in minette dykes. a - Magnetic anisotropy P-T plot. b-g - Orientations of magnetic lineations (squares) and magnetic foliation poles (circles). Equal-area projection on lower hemisphere. Ellipses represent confidence areas. gated at four localities. The degree of AMS is very low in most specimens, only rarely slightly higher (mainly in KV-Ma dyke) (Fig. 11a). The shape of the AMS ellipsoid ranges from very prolate to almost perfectly oblate (Fig. 11a). In three dykes (KV-KU, KV-NH, KV-Ma), the magnetic foliation is relatively near the dyke plane (Figs 11b-d; 12a-b). At two localities (KV-Ni and KV-Ma), the magnetic foliation scatters widely, creating a wide girdle in its poles, at a large angle with the dyke margins (Figs $11 \mathrm{~d}-\mathrm{e} ; 12 \mathrm{a}-\mathrm{b}$ ). The magnetic lineation is very roughly parallel to the dyke plane in all four dykes, being virtually horizontal in $\mathrm{KV}$-NH and creating girdles very near to dyke plane in KV-KU and KV-Ma (Fig. 11b-d). In the dyke $\mathrm{KV}-\mathrm{Ni}$, the magnetic lineations of the most specimens are sub-horizontal or show only mild plunges, even though there are also a few specimens that plunge moderately to steeply (Figs 11e, 12a). In the dyke KV$\mathrm{NH}$, the magnetic fabric corresponds well to the Type $\mathrm{Ib}$

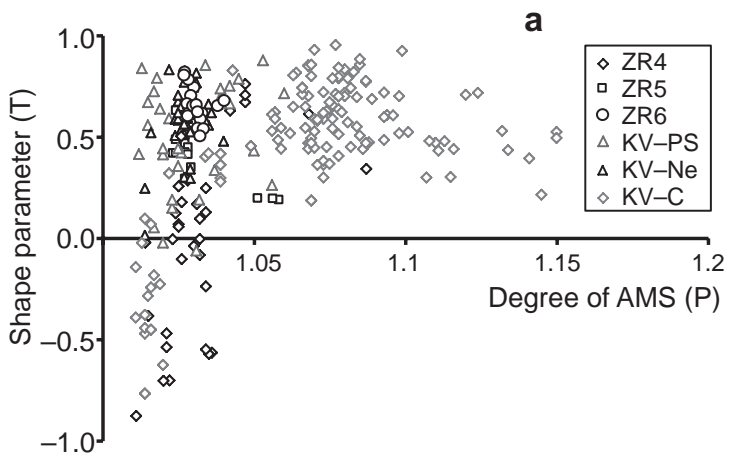

b) ZR -4 minette

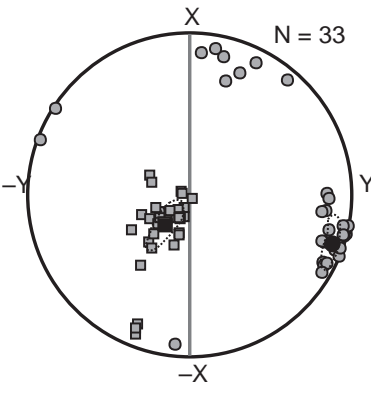

c) ZR-5 minette

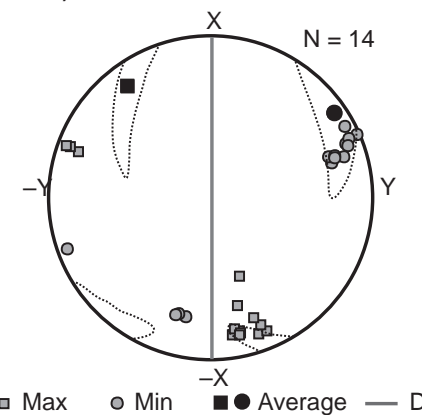

d) ZR-6 minette

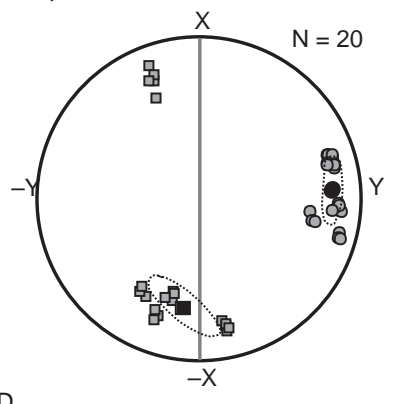

e) KV-PS minette

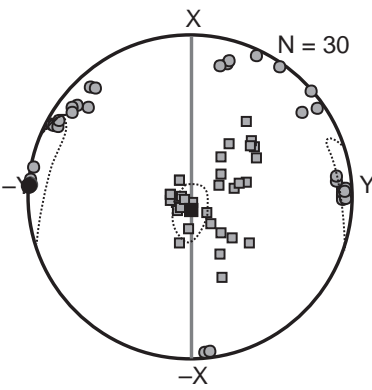

f) KV-Ne minette

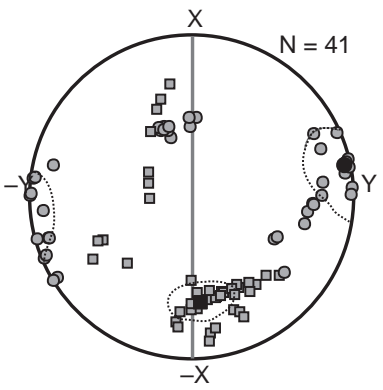

g) KV-C minette

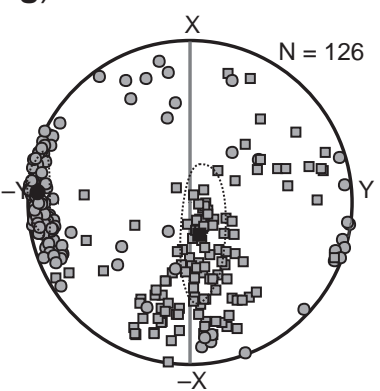

$\square \operatorname{Max}$
- Average
$-\mathrm{D}$ 
fabric which evidently originated from relatively free flow. The horizontal magnetic lineations indicate that the flow was horizontal. The magnetic fabric in the dykes $\mathrm{KV}$-KU and KV-Ma in principle also corresponds to the Type I (in fact transition between Type Ia and Type Ib). However, the mean magnetic foliation differs from the dyke azimuthally by $c$. $20^{\circ}$. We ascribe this difference rather to measurement error in the dyke orientation due to local unevenness of the dyke plane rather than to the flow oblique with respect to the dyke plane. The girdle in magnetic lineations suggests that the magma flow may have been complex, spatially varying from vertical to horizontal.

\subsection{Spessartite dykes}

In addition to the locality ZR-1 where spessartite occurs in a composite dyke consisting of three rock types (see Section 6.1) and whose degree of AMS is very low (see Fig. 9a), this rock was investigated in the dykes ZR-3 and $\mathrm{KV}$-Se. In the dyke ZR-3, the degree of AMS is an order of magnitude higher but in the host granite it is very low. The dyke KV-Se (Fig. 13a) shows highly variable, low to high, degree of AMS.

The shape of the AMS ellipsoid ranges from moderately prolate to strongly oblate at all three localities (Fig. 13a). In the most strongly anisotropic specimens, it is neutral to weakly prolate. Both the magnetic foliation and lineation in the dyke ZR-3 are oblique with respect to

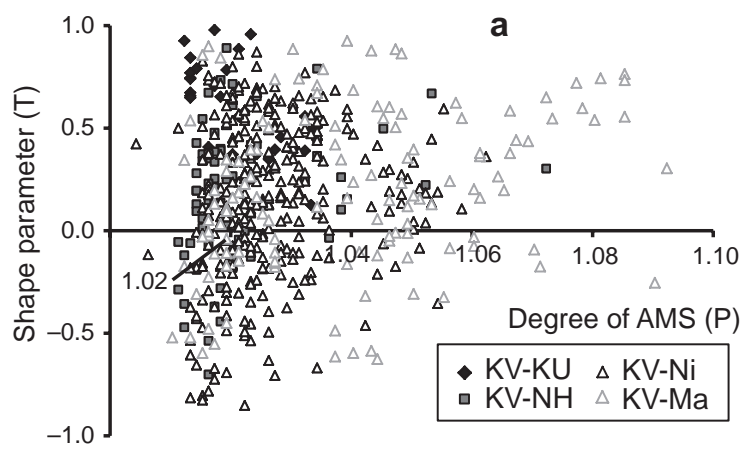

c) KV-NH porphyry

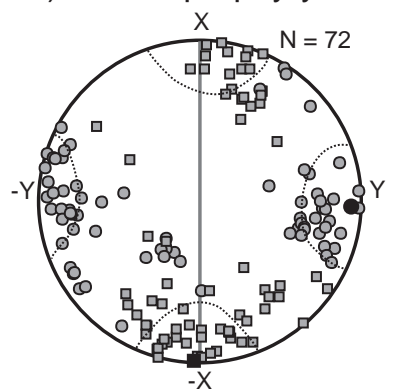

d) KV-Ma porphyry

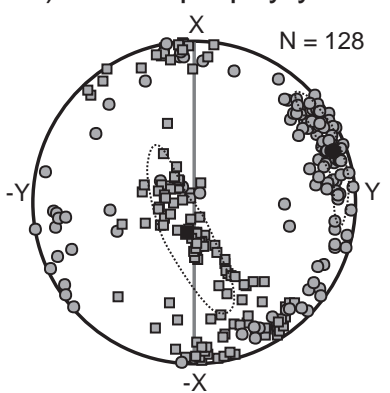

口 Max o Min b) KV-KU porphyry

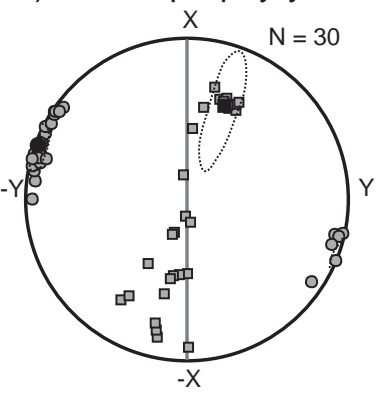

e) KV-Ni porphyry

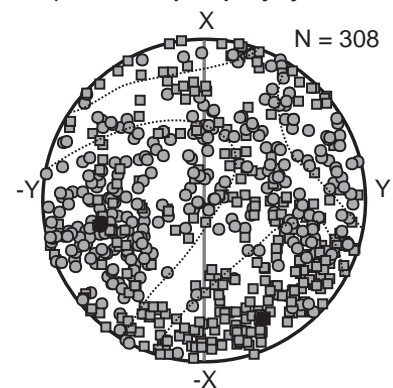

- D the dyke (Fig. 13b). The magnetic foliation and lineation in the host granite are almost precisely perpendicular to the dyke (Fig. 13c). In KV-Se dyke, both magnetic foliation and magnetic lineation are perpendicular to the dyke margins (Type IIIb; Fig. 13d). In neither of the spessartite dykes investigated, the magnetic fabric corresponds to the generally most common Type I. It means that the movement of the spessartite magma did not resemble the free flow known mainly from minette magmas but was much more complex.

\section{Discussion}

Almost two thirds of the dykes investigated show Type I magnetic fabric characterized by approximate parallelism of the magnetic foliation and magnetic lineation to the dyke plane. The magnetic lineation is mostly nearly horizontal and only exceptionally vertical. This magnetic fabric type is commonly assumed to originate through magma flow within the dyke (e.g. Raposo 2011). It is interesting that the flow directions inferred from magnetic lineations are horizontal and only exceptionally vertical. Consequently, the dyke magma propagated through horizontal flow, which may indicate that the dykes investigated are not located above the magma source.

In the Dobrríš composite dyke, the innermost hornblendite shows Type Ia magnetic fabric, the outermost spessartite Type IIIa, and the kersantite in between Type IIIb. Only hornblendite therefore experienced relatively free flow of magma, while the mechanisms of kersantite and spessartite magma movement were more complex.

The magnetic fabric in kersantite is precisely inverse to that in hornblendite. The first, geological explanation of this phenomenon assumes dramatically different magma movement in both rock types and the second, physical explanation assumes that the grains of the magnetic minerals carrying the AMS were very small, virtually single domain (SD) particles in one of the rock types. As shown

Fig. 11 Pattern of the AMS in porphyry dykes. a - Magnetic anisotropy P-T plot. b-e - Orientations of magnetic lineations (squares) and magnetic foliation poles (circles). Equal- area projection on lower hemisphere. Ellipses represent confidence areas. 


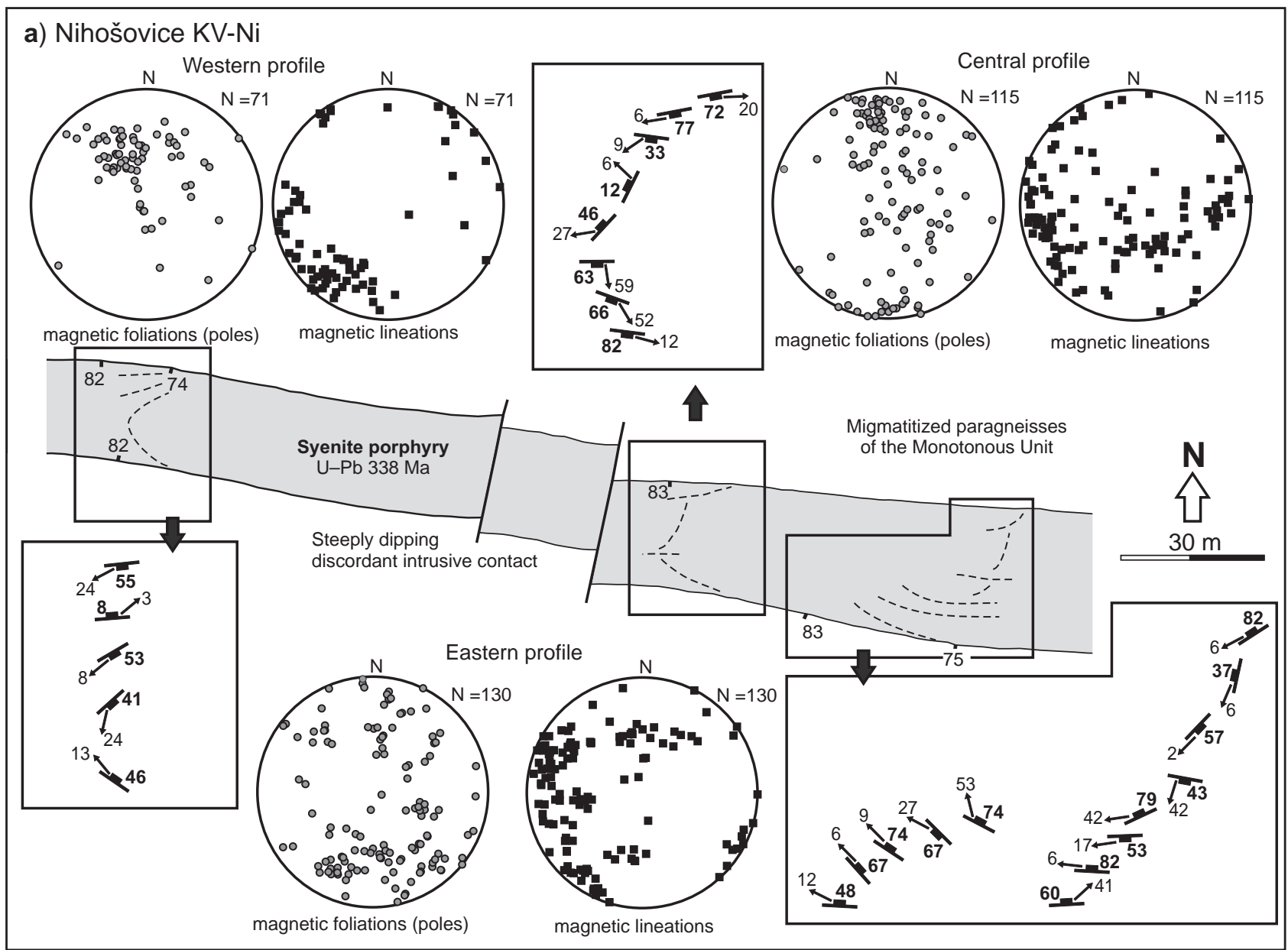

b) Malčice KV-Ma

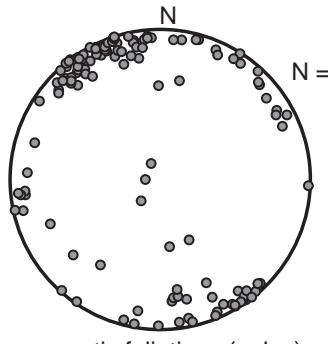

magnetic foliations (poles)

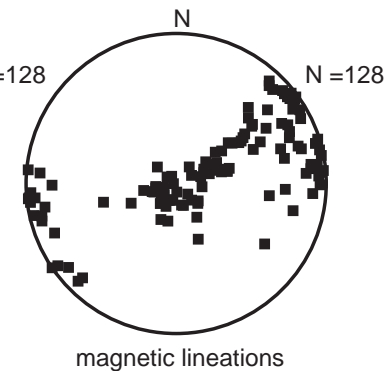

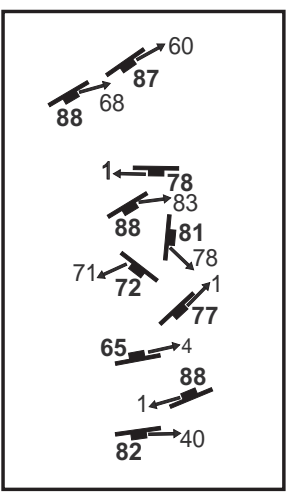

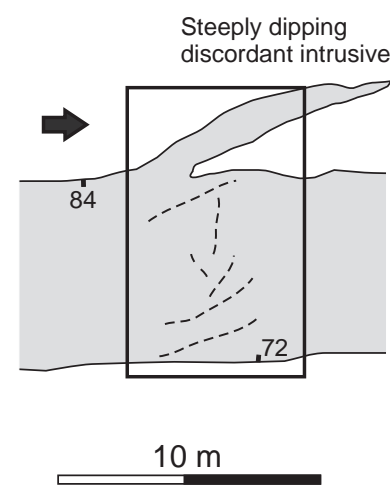

Fig. 12 Structural scheme of porphyry dykes showing magnetic fabric pattern and trajectories of the magnetic foliation at: a - Nihošovice (KV-Ni) and $\mathbf{b}$ - Malčice (KV-Ma).

by Potter and Stephenson (1988) for example, the maximum susceptibility is along the minimum axis, while the minimum susceptibility is along the maximum dimension of a SD particle.

Were the second, physical explanation true, the magnetic particles would define the most frequent fabric type whereby the larger planes of magnetic minerals are aligned parallel to the dyke plane and their longer dimen- sions are parallel to the flow direction within the dyke. However, the susceptibility variation with temperature is very similar in hornblendite and kersantite. In addition, the frequency-dependent susceptibility is in these rock types relatively low (mostly $X_{\mathrm{FD}}=2-3 \%$ ) indicating that the ultrafine magnetically viscous particles on transition from superparamagnetic (SP) to SD state are indeed present, albeit in relatively small amounts. Assuming grain-size 
distribution continuous from SP, through SD to MD, and realizing that the susceptibility of SD particles is lower than that of MD or SP particles, the relatively low values of frequency-dependent susceptibility may indicate that the SD particles are not abundant enough to dominate the rock magnetism. All this makes the physical explanation very unlikely and the above phenomenon should be ascribed to different mechanisms in detail magma movement.

In spessartite, the magnetic fabric is of the Type IIIa. We assume that the magma flow was not free because the injected joint was not fully open or was filled in with initial portions of magma. Consequently, the magma movement resembled that of forceful injection. The magnetic minerals were then orientated with their larger surfaces perpendicular to the magma movement and the magnetic foliation was horizontal. The existence of magnetic lineations perpendicular to the dyke can be explained by a mechanism when joint, gradually filled with the magma, was simultaneously widened and the magma also flew horizontally on a small scale.

The studied dykes are mostly perpendicular to the elongation of the CBPC as well as to magmatic to subsolidus fabrics in individual plutons and regional metamorphic fabrics in the WMZ. In addition, the dykes are parallel with the direction of regional $\sim$ WNW-ESE crustal convergence during the main phase of the Variscan Orogeny at $\sim 355$ to $340 \mathrm{Ma}$ (e.g. Žák et al. 2005a, b, 2009; Schulmann et al. 2009; Faryad and Žák 2016). Therefore, we can assume that NW(W)-SE(E) trending extensional joints and accompanying dykes originated synchronously during dilatation

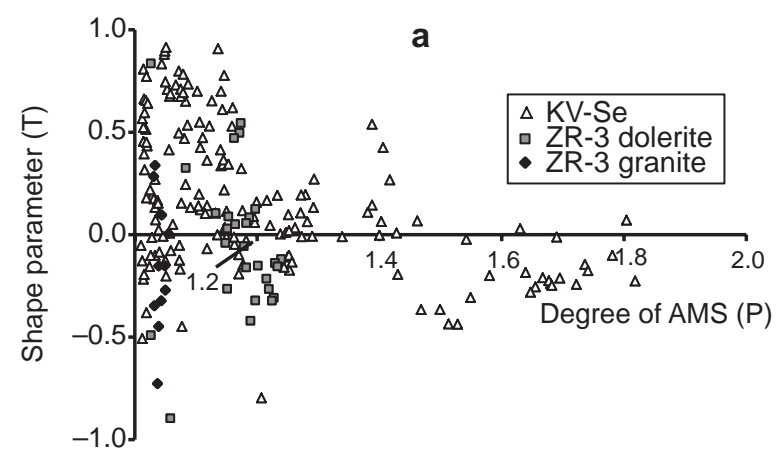

b) ZR -3 dolerite

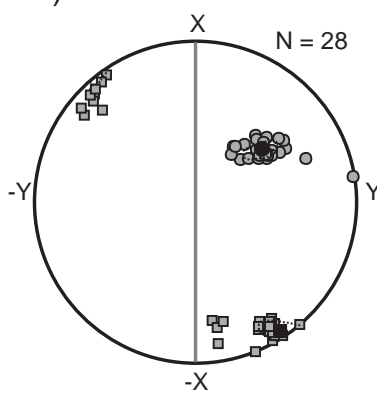

c) ZR -3 granite

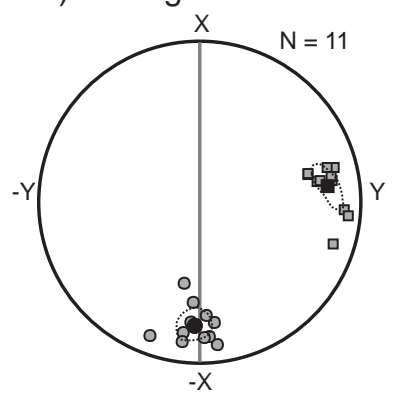

d) KV-Se spessartite

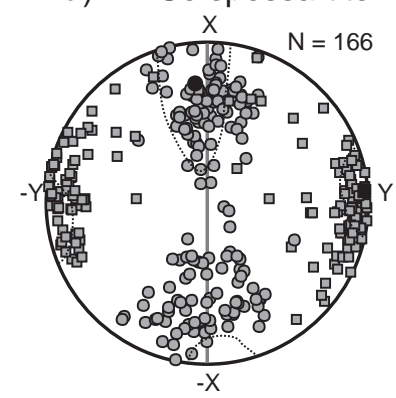

(orogen arc-parallel stretching) which was perpendicular to their intrusive contacts.

Analyses of fabric pattern and AMS have been applied for identification of the direction of initial magma flow through dykes (e.g. Varga et al. 1998; Geoffroy et al. 2002). In general, magnetic lineations are usually subparallel to the direction of magma flow (Callot et al. 2001; Callot and Geoffroy 2004). Relics of steeply dipping magnetic lineations which have been identified mainly in the central parts of the dykes indicate an originally vertical flow direction during magma ascent after dyke propagation, mainly in marginal parts of the dykes. However, predominant subhorizontal magmatic lineation (0 to $40^{\circ}$ to $\sim \mathrm{W}$ to $\mathrm{WNW}$ ) suggests changes in rate and direction of magma flow. The reason can be increasing viscosity of the magma (e.g. Petford 1996; Mathieu et al. 2008) and/ or effect of regional stress field (Féménias et al. 2004). Indeed, the regional stress conditions in the WMZ changed from the NW-SE compression to subvertical shortening of the crust due to exhumation of orogenic root domain (e.g. Verner et al. 2008; Žák et al. 2012). In addition, rare imbrication of magnetic foliation (e.g. Geoffroy et al. 2002) with respect to the intrusive contacts of the dyke (e.g. at Nihošovice; Figs 11e, 12a) indicates the redirection of magma flow from east to west.

\section{Conclusions}

The investigations of magnetic fabrics in the calc-alkaline to (ultra)potassic lamprophyre dykes of the Central Bohemian Dyke Swarm (Bohemian Massif, Czech Republic) have drawn the following conclusions:

(a) Even though various magnetic phases, represented by various $\mathrm{Fe}-\mathrm{Ti}$ oxides, were identified in the dykes investigated, it is magnetite or low-Ti titanomagnetite that is evidently the principal carrier of rock susceptibility as well as of the

Fig. 13 Pattern of the AMS in spessartite/dolerite dykes (ZR-3 and KV-Se) and host granite. a - Magnetic anisotropy $\mathrm{P}-\mathrm{T}$ plot. Orientations of magnetic lineations (squares) and magnetic foliation poles (circles): $\mathbf{b}$ - in spessartite/ dolerite dyke (locality ZR-3); c - in host-rock granite (locality ZR-3) and d - in spessartite dyke (locality KV-Se). Equal-area projection on lower hemisphere. Ellipses represent confidence areas. 
AMS. As the AMS of this mineral is controlled by the grain shape, the rock's AMS reflects its grain-preferred orientation. The contributions of the other Fe-Ti oxides to the rock susceptibility are low. In one dyke, the predominating carrier of susceptibility is pyrrhotite, the AMS of which is controlled by the lattice-preferred orientation of grains. The intensity of this effect depends on the pyrrhotite and magnetite/titanomagnetite proportions.

(b) The magnetic fabric in the most dykes is conformable to the dyke shapes. This corresponds to the most common type of magnetic fabric in dykes the world over (Type I; Raposo and Ernesto 1995), which no doubt originates through a magma flow, during which the larger surfaces of magnetic minerals orient approximately parallel to the dyke, while the longer dimensions orient parallel to the magma flow direction. It is considered to be relatively free flow that requires relatively open, likely extensional structures. The flow directions inferred from magnetic lineations are horizontal and only exceptionally vertical suggesting that the magma propagated through horizontal flow within the dyke. This may indicate that the dykes investigated were not located immediately above the magma source.

(c) In most spessartite dykes, both the magnetic foliation and magnetic lineation are perpendicular to the dyke, thus corresponding to the magnetic fabric Type III of Raposo and Ernesto (1995). We assume that the magma movement had character of forceful injection. The larger surfaces of the magnetic minerals were oriented perpendicular to the magma movement and the long dimensions of the same minerals oriented perpendicular to the progressively widened dyke.

(d) In the Dobříš composite dyke, the innermost hornblendite shows Type Ia magnetic fabric, the outermost spessartite Type IIIa, and the kersantite located in between Type IIIb. Only hornblendite, therefore, indicates relatively free flow of magma, while the mechanisms of magma movement in kersantite and spessartite were more complex, possibly changing during the generation of that single composite dyke.

(e) Studied dykes were emplaced into already juxtaposed the Teplá-Barrandian Zone, Central Bohemian Plutonic Complex and exhumed western Moldanubian Zone at $\sim 346$ to $337 \mathrm{Ma}$. Identical orientation of dykes (steep intrusive contacts in $\mathrm{W}(\mathrm{NW})-\mathrm{E}(\mathrm{SE})$ trend was caused by the regional stress field of $\sim$ WNW-ESE convergence (arc-parallel stretching) and subvertical shortening of due to crustal exhumation of the Variscan orogen root.

Acknowledgements. We would like to gratefully acknowledge the contribution of Michael Petronis and Arnošt Dudek through their very constructive reviews, which greatly assisted in improving the original manuscript. Vladislav Rapprich is acknowledged for his helpful comments and careful editorial handling of the manuscript. Lucie Orságová and Martina Studená are greatly thanked for assistance with sampling and measuring AMS. The research was financially supported by the Czech Science Foundation (GACR-FWF No. 15-34621L to K. Verner).

Electronic supplementary material. The values of the mean susceptibility (Km), degree of AMS (P), shape parameter $(\mathrm{T})$ as well as the orientations of the maximum (K1), intermediate (K2), and minimum (K3) susceptibilities in terms of azimuth (prefix d) and plunge (prefix i) in geographic coordinates for individual specimens are available online at the Journal web site (http://dx.doi. org/10.3190/jgeosci.222).

\section{References}

Aydin A, Ferré EC, Aslan Z (2007) The magnetic susceptibility of granitic rocks as a proxy for geochemical differentiation: example from the Saruhan granitoids, NE Turkey. Tectonophysics 441: 85-95

Bates MP, Mushayandebvu MF (1995) Magnetic fabric in the Umvimeela Dyke, satellite of the Great Dyke, Zimbabwe. Tectonophysics 242: 141-254

Callot JP, Geofrroy L (2004) Magma flow in the East Greenland dyke swarm inferred from study of anisotropy of magnetic susceptibility: magmatic growth of a volcanic margin. Geophys J Inter 159: 816-830

Callot JP, Geoffroy L, Aubourg C, Pozzi JP, Mege D (2001) Magma flow directions of shallow dykes from the East Greenland volcanic margin inferred from magnetic fabric studies. Tectonophysics 335: 3-4

CAÑón-TAPIA E (2004) Anisotropy of magnetic susceptibility of lava flows and dykes: a historical account. In: MARTINHernandez F, Luneburg CM, Aubourg C, JaCkson M(eds) Magnetic Fabric: Methods and Applications. Geological Society of London Special Publications 238: pp 205-225

Chadima M, Jelínek V (2008) Anisoft 4.2 - anisotropy data browser. Contrib Geophys Geodesy 38: 41 (Special Issue)

Chalapathi Rao NV, Srivastava RK (2012) Kimberlites, lamproites, lamprophyres, their entrained xenoliths, mafic dykes and dyke swarms: highlights of recent Indian Research. Proc Indian Nat Sci Acad 78: 431-444

Chlupáč I, HavlíčEK V, KŘiž J, KuKAl Z, ŠtorCh P (1998) Paleozoic of the Barrandian (Cambrian to Devonian). Czech Geological Survey, Prague, pp 1-183

Chlupáč I, Brzobohatý R, Kovanda J, Stráník Z (2002) Geological History of the Czech Republic. Academia, Prague, pp 1-436 (in Czech)

Dearing JA, Dann RJl, Hay K, Lees Ja, Loveland PJ, Maher BA, O'Grady K (1996) Frequency-dependent susceptibility measurements of environmental materials. Geophys J Int 124: 228-240 
Dunlop DJ, Özdemir Ö (1997) Rock Magnetism. Fundamentals and Frontiers. Cambridge University Press, Cambridge, pp 1-573

De Wall H (2000) The field dependence of AC susceptibility in titanomagnetites: implications for the anisotropy of magnetic susceptibility. Geophys Res Lett 27: 2409-2411

De Wall H, Nano L (2004) The use of field dependence of magnetic susceptibility for monitoring variations in titanomagnetite composition: a case study on basanites from the Vogelsberg 1996 Drillhole, Germany. Stud Geophys Geod 48: 767-776

DöRr W, ZuLAuf G (2010) Elevator tectonics and orogenic collapse of a Tibetan-style plateau in the European Variscides: the role of the Bohemian shear zone. Int J Earth Sci (Geol Rundsch) 99: 299-325

Edgar AD, Mitchell RH (1997) Ultra high pressure-temperature melting experiments on an $\mathrm{SiO}_{2}$-rich lamproite from Smoky Butte, Montana: Derivation of siliceous lamproite magmas from enriched sources deep in the continental mantle. J Petrol 38, 457-477.

ERNSt RE, BARAGAR WRA (1992) Evidence from magnetic fabric for the flow pattern of magma in the Mackenzie giant radiating dyke swarm. Nature 356: 511-513

EYRE JK (1997) Frequency dependence of magnetic susceptibility for populations of single-domain grains. Geophys J Int 129: 209-211

FARYAD SW, ŽÁK J (2016) High-pressure granulites of the Podolsko Complex, Bohemian Massif: an example of crustal rocks that were subducted to mantle depths and survived a pervasive mid-crustal high-temperature overprint. Lithos 246-247: 246-260

Faryad SW, Nahodilová R, Dolejš D (2010) Incipient eclogite facies metamorphism in the Moldanubian granulites revealed by mineral inclusions in garnet. Lithos 114: 54-69

Faryad S W, JedličKa R, Collett S (2013) Eclogite facies rocks of the Monotonous Unit, clue to Variscan suture in the Moldanubian Zone (Bohemian Massif) Lithos 179: 353-363

Féménias O, Diot H, Berza T, Gauffriau A, Demaiffe D (2004) Asymmetrical to symmetrical magnetic fabric of dikes: paleo-flow orientations and paleo-stresses recorded on feeder-bodies from the Motru Dike Swarm (Romania). J Struct Geol 26: 1401-1418

Franke W (2006) The Variscan orogen in Central Europe: construction and collapse. In: GeE DG, STEPHENSON, RA (eds), European Lithosphere Dynamics. Geological Society of London Memoirs 32: pp 333-343

Geoffroy L, Callot JP, Aubourg C, Moreira M (2002) Magnetic and plagioclase linear fabric discrepancy in dykes: a new way to define the flow vector using magnetic foliation. Terra Nova 14: pp 183-190

Guo Z, Wilson M, Liu J, Mao Q (2006) Post-collisional, potassic and ultrapotassic magmatism of the northern
Tibetan Plateau: constraints on characteristics of the mantle source, geodynamic setting and uplift mechanisms. J Petrol 47: 1177-1220

GuPTA AK (2015) Origin of Potassium-Rich Silica-Deficient Igneous Rocks. Springer, Berlin, New York, pp 1-536

HAJNÁ J, Ž́́́K J, DöRr W (2017) Time scales and mechanisms of growth of active margins of Gondwana: a model based on detrital zircon ages from the Neoproterozoic to Cambrian Blovice accretionary complex, Bohemian Massif. Gondwana Res 42: 63-83

HenRy B (1977) Relations entre deformations et proprietes magnétiques dans des roches volcaniques des Alpes francaises. Mem BRGM 91: 79-86

Holub FV (1997) Ultrapotassic plutonic rocks of the durbachite series in the Bohemian Massif: petrology, geochemistry and petrogenetic interpretation. Sbor geol Věd, ložisk Geol Mineral 31: 5-26

Holub F (2003) Zonal dyke of ocelli lamprophyre to hornblendite from Dobříš. Zpr Geol Výzk v r 2003: 106-108 (in Czech)

Holub FV, KlečKa M, MatĚJKa D (1995) Igneous activity. In: Dallmeyer RD, Franke W, Weber K (eds) PrePermian geology of Central and Eastern Europe. Springer Verlag, Berlin, pp 444-452

Holub FV, Cocherie A, Rossi P (1997a) Radiometric dating of granitic rocks from the Central Bohemian Plutonic Complex (Czech Republic): constraints on the chronology of thermal and tectonic events along the Moldanubian-Barrandian boundary. C R Acad Sci Paris, Sciences de la Terre et des planétes 325: 19-26

Holub FV, Machart J, Manová M (1997b) The Central Bohemian Plutonic Complex: geology, chemical composition and genetic interpretation. Sbor geol Věd, ložisk Geol Mineral 31: 27-50

Holub FV, Studená M, Vosk M (2007) Dolerites and gabbro to diorite porphyries in the Central Bohemian Plutonic Complex. Zpr geol Výzk v r 2006: 127-129 (in Czech)

Holub FV, Verner K, Studená M, Orságová L (2009) Dyke swarms of ultrapotassic melasyenite to melagranite porphyries from the Central Bohemian Plutonic Complex and the Šumava part of the Moldanubicum. Zpr geol Výzk v r 2008: 17-20 (in Czech)

Holub FV, Schmitz MD, Verner K, Janoušek V, Veselovský F (2010) Geochemical and temporal relations of ultrapotassic plutons and dyke swarms in South Bohemia. In: Конúт M (eds) Datovanie 2010. Zborník abstraktov. Štátny geologický ústav Dionýza Štúra, Bratislava, pp 13-14

Holub FV, Verner K, Schmitz MD (2012) Temporal relations of melagranite porphyry dikes and durbachitic plutons in South Bohemia. Zpr Geol Výzk v r 2011: 23-25 (in Czech)

Hrouda F (1985) The magnetic fabric in the Brno Massif. Sbor Geol Věd, Už Geol 19: 89-112 
Magnetic fabrics of lamprophyres and related rocks, Bohemian Massif

Hrouda F (2002) Low-field variation of magnetic susceptibility and its effect on the anisotropy of magnetic susceptibility of rocks. Geophys J Int 150: 715-723

Hrouda F (2011) Models of frequency-dependent susceptibility of rocks and soils revisited and broadened. Geophys J Int 187: 1259-1269

Hrouda F, Pokorný J (2011) Extremely high demands for measurement accuracy in precise determination of frequency-dependent magnetic susceptibility of rocks and soils. Stud Geophys Geod 55: 667-681

Hrouda F, Přichystal A (1995) Magnetic fabric relationship between Palaeozoic volcanic and sedimentary rocks in the Nízký Jeseník Mts. (NE Moravia). J Czech Geol Soc 40: 91-102

Hrouda F, V Jelínek V, HruŠKová L (1990) A package of programs for statistical evaluation of magnetic anisotropy data using IBM-PC computers. Eos Trans Am Geophys Union (Fall meeting 1990), Conference Abstract, pp 1289

Hrouda F, Chlupáčová M, Mrázová Š (2006) Low-field variation of magnetic susceptibility as a tool for magnetic mineralogy of rocks. Phys Earth Sci Inter 154: 323-336

Hrouda F, Faryad SW, Chlupáčová M, Jeřábek P, Vitouš P (2009) Determination of field-independent and fielddependent components of anisotropy of susceptibility through standard AMS measurements in variable low fields II: An example from the ultramafic body and host granulitic rocks at Bory in the Moldanubian Zone of Western Moravia, Czech Republic. Tectonophysics 466: 123-134

Jackson M, Moskowitz B, Rosenbaum J, Kissel C (1998) Field-dependence of AC susceptibility in titanomagnetites. Earth Planet Sci Lett 157: 129-139

JANOUŠEK V, HoLuB FV (2007) The causal link between HPHT metamorphism and ultrapotassic magmatism in collisional orogens: case study from the Moldanubian Zone of the Bohemian Massif. Proc Geol Assoc 118: 75-86

JANOUŠEK V, Rogers G, Bowes DR (1995) Sr-Nd isotopic constraints on the petrogenesis of the Central Bohemian Pluton, Czech Republic. Geol Rundsch 84: 520-534

Janoušek V, Bowes DR, Rogers G, Farrow CM, Jelínek E (2000) Modelling diverse processes in the petrogenesis of a composite batholith: the Central Bohemian Pluton, Central European Hercynides. J Petrol 41: 511-543

JANOUŠEK V, Braithwaite CJR, Bowes DR, Gerdes A (2004) Magma-mixing in the genesis of Hercynian calc-alkaline granitoids: an integrated petrographic and geochemical study of the Sázava intrusion, Central Bohemian Pluton, Czech Republic. Lithos 78: 67-99

JANOUŠEK V, WiEGAND B, ŽÁK J (2010) Dating the onset of Variscan crustal exhumation in the core of the Bohemian Massif: new U-Pb single zircon ages from the high-K calcalkaline granodiorites of the Blatná suite, Central Bohemian Plutonic Complex. J Geol Soc, London 167: 347-360

Janoušek V, Holub FV, Gerdes A, Verner K (2013) Twopyroxene syenitoids from the Moldanubian Zone of the Bohemian Massif: peculiar magmas derived from a strongly enriched lithospheric mantle source. Geophys Res Abstr 15: EGU2013-11746

JELíNEK V (1978) Statistical processing of magnetic susceptibility measured on groups of specimens. Stud Geophys Geod 22: 50-62

JELíNEK V (1981) Characterization of the magnetic fabric of rocks. Tectonophysics 79: 63-67

JeLíneK V, PoKornÝ J (1997) Some new concepts in technology of transformer bridges for measuring susceptibility anisotropy of rocks. Phys Chem Earth 22: 179-181

KNight MD, Walker GPL (1988) Magma flow directions in dykes of the Koolan Complex, Oahu, determined from magnetic fabric studies. J Geophys Res 93: 4308-4319

Košler J, Konopásek J, Sláma J, Vrána S (2014) U-Pb zircon provenance of Moldanubian metasediments in the Bohemian Massif. J Geol Soc, London 171: 83-95

Kubínová Š, Faryad SW, Verner K, Schmitz M, Holub FV (2017) Ultrapotassic dykes in the Moldanubian Zone and their significance for understanding post-collisional mantle dynamics during the Variscan orogeny in the Bohemian Massif. Lithos 272-273, 205-221.

Lardeaux JM, Schulmann K, Faure M, Janoušek V, Lexa O, Skrzypek E, Edel JB, Štípská P (2014) The Moldanubian Zone in French Massif Central, Vosges/Schwarzwald and Bohemian Massif revisited: differences and similarities. In: Schulmann K, Martínez Catalán JR, LARDEAuX JM, JANOUŠEK V, OGgIANo G (eds) The Variscan Orogeny: Extent, Timescale and the Formation of the European Crust. Geological Society, London, Special Publications 405, pp 7 -44

Le Bas M ., Le Maitre R W, Streckeisen A, Zanettin B (1986) A chemical classification of volcanic rocks based on the total alkali-silica diagram. J Petrol 27: 745-750

Machek M, Roxerová Z, Závada P, Silva PF, Henry B, DĚdeček P, Petrovský E, Marques FO (2014) Intrusion of lamprophyre dyke and related deformation effects in the host rock salt: a case study from the Loule diapir, Portugal. Tectonophysics 629: 165-178

Mathieu L, De Vries BVW, Holohan EP, Troll VR (2008) Dykes, cups, saucers and sills: analogue experiments on magma intrusion into brittle rocks. Earth Planet Sci Lett 271: $1-13$

Nagata T (1961) Rock Magnetism. Maruzen, Tokyo, pp 1-366

Park JK, Tanczyk EI, Desbarats A (1988) Magnetic fabric and its significance in the 1400 Ma Mealy diabase dykes of Labrador, Canada. J Geophys Res 93: 689-704

Parma J, Hrouda F, Pokorný J, Wohlgemuth J, Suza P, Šlingaer P, Zapletal K (1993) A technique for measuring temperature dependent susceptibility of weakly magnetic rocks. EOS Trans AGU 1993: 113 
Peccerillo A, TAYlor SR (1976) Geochemistry of Eocene calc-alkaline volcanic rocks from the Kastamonu area, Northern Turkey. Contrib Mineral Petrol 58: 63-81

PETFORd N (1996) Dykes or diapirs? In: Brown M, CANDELA PA, Peck DL, Stephens WE, Walker RJ, Zen EA (eds) The Third Hutton Symposium on the Origin of Granites and Related Rocks. Geological Society of America Special Papers 315: pp 105-114

Petrovský E, KapičKa A (2006) On determination of the Curie point from thermomagnetic curves. J Geophys Res 111: B12S27

Pokorný J, Pokorný P, Suza P, Hrouda F (2011) A multifunction Kappabridge for high precision measurement of the AMS and the variations of magnetic susceptibility with field, temperature and frequency. In: Petrovský E, Herrero-Bervera T, Harinarayana DI (eds) The Earth's Magnetic Interior. IAGA Special Sopron Book Series 1: Springer, Berlin, pp 292-301

Potter DK, Stephenson A (1988) Single-domain particles in rocks and magnetic fabric analysis. Geophys Res Lett 15: $1097-1100$

Raposo MIB (2011) Magnetic fabric of the Brazilian dike swarms. A review. In: Petrovský E, Herrero-Bervera E, Harinarayana T, Ivers D (eds) The Earth's Magnetic Interior. IAGA Special Sopron Book Series 1: Springer, Berlin, pp 247-262

RAposo MIB, ERnEsto M (1995) Anisotropy of magnetic susceptibility in the Ponta Grossa dyke swarm (Brazil) and its relationship with magma flow direction. Phys Earth Planet Inter 87: 183-196

Rochette P, Jenatton L, Dupuy C, Boudier F, Reuber I (1991) Diabase dykes emplacement in the Oman ophiolite: a magnetic fabric study with reference to geochemistry. In: Peters TJ, Nicolas A, Coleman R (eds) Ophiolite Genesis and Evolution of the Oceanic Lithosphere. Kluwer, Dordrecht, pp 55-82

Schulmann K, Konopásek J, Janoušek V, Lexa O, Lardeaux JM, Edel JB, ŠTíPská P, Ulrich S (2009) An Andean type Palaeozoic convergence in the Bohemian Massif. C R Geosci 341: 266-286

Stephenson A, SAdikum S, Potter DK (1986) A theoretical and experimental comparison of the anisotropies of magnetic susceptibility and remanence in rocks and minerals. Geophys J Astron Soc 84: 185-200

StudýnKa J, Chadima M, Suza P (2014) Fully automated measurement of anisotropy of magnetic susceptibility using 3D rotator. Tectonophysics 629: 6-13

Tarling DH, Hrouda F (1993) The Magnetic Anisotropy of Rocks. Chapman \& Hall, London, pp 1-217

Urban M, Synek J (1995) Moldanubian Zone: Structure. In: Dallmeyer RD, Franke W, Weber K (eds) Pre-Permian Geology of Central and Eastern Europe. Springer Verlag, Berlin, pp 429-424
Varga RJ, Gee JS, Staudigel H, Tauxe L (1998) Dike surface lineations as magma flow indicators within the sheeted dike complex of the Troodos ophiolite, Cyprus. J Geophys Res 103: 5241-5256

Verner K, Žák J, Nahodilová R, Holub F (2008) Magmatic fabrics and emplacement of the cone-sheet-bearing Knížecí Stolec durbachitic pluton (Moldanubian Unit, Bohemian Massif): implications for mid-crustal reworking of granulitic lower crust in the Central European Variscides. Int J Earth Sci 97: 19-33

Worm HU (1998) On the superparamagnetic-stable single domain transition for magnetite, and frequency dependence of susceptibility. Geophys J Int 133: pp 201-206

Worm HU, Clark D, Dekrers MJ (1993) Magnetic susceptibility of pyrrhotite: grain size, field and frequency dependence. Geophys J Int 114: 127-137

ŽÁk J, Schulmann K, Hrouda F (2005a) Multiple magmatic fabrics in the Sázava pluton (Bohemian Massif, Czech Republic): a result of superposition of wrench-dominated regional transpression on final emplacement. J Struct Geol 27: 805-822

ŽÁk J, Holub FV, Verner K (2005b) Tectonic evolution of a continental magmatic arc from transpression in the upper crust to exhumation of mid-crustal orogenic root recorded by episodically emplaced plutons: the Central Bohemian Plutonic Complex (Bohemian Massif). Int J Earth Sci 94: 385-400

Žák J, Dragoun F, Verner K, Chlupáčová M, Holub FV, KACHLíK V (2009) Forearc deformation and strain partitioning during growth of a continental magmatic arc: the northwestern margin of the Central Bohemian Plutonic Complex, Bohemian Massif. Tectonophysics 469: 93-111

Žák J, Kratinová Z, Trubač J, Janoušek V, Sláma J, Mrlina J (2011) Structure, emplacement, and tectonic setting of Late Devonian granitoid plutons in the Teplá-Barrandian Unit, Bohemian Massif. Int J Earth Sci (Geol Rundsch) 100: 1477-1495

Žák J, Verner K, Holub FV, Kabele P, Chlupáčová M, HaLOdOVÁ P (2012) Magmatic to solid state fabrics in syntectonic granitoids recording early Carboniferous orogenic collapse in the Bohemian Massif. J Struct Geol 36: 27-42

ŽÁk J, Verner K, Janoušek V, Holub FV, Kachlík V, Finger F, Hajná J, Tomek F, Vondrovic L, Trubač J (2014) A plate-kinematic model for the assembly of the Bohemian Massif constrained by structural relationships around granitoid plutons. In: Schulmann K, Martínez Catalán JR, Lardeaux JM, Janoušek V, Oggiano G (eds) The Variscan Orogeny: Extent, Timescale and the Formation of the European Crust. Geological Society, London, Special Publications 405, pp 169-196

ŽEŽULKOVÁ V (1982) Žilné horniny jižní části středočeského plutonu. Sbor geol Věd, Geol 37: 71-102 